\title{
Multiple gas reservoirs are responsible for the gas emissions along the Marmara fault network
}

\author{
Ruffine Livio ${ }^{1,{ }^{*}}$, Donval Jean-Pierre ${ }^{1}$, Croguennec Claire ${ }^{1}$, Burnard Pete ${ }^{2}$, Lu Hailong ${ }^{3}$, \\ Germain Yoan ${ }^{1}$, Legoix Ludovic ${ }^{1,4}$, Bignon Laurent ${ }^{5}$, Çağatay M. Namık ${ }^{6}$, Marty Bernard ${ }^{2}$, \\ Madre David ${ }^{2}$, Pitel-Roudaut Mathilde ${ }^{1}$, Henry Pierre ${ }^{7}$, Géli Louis ${ }^{1}$
}

${ }^{1}$ IFREMER, Département Ressources physiques et Ecosystèmes de fond de Mer (REM), Unité des Géosciences Marines, 29280 Plouzané, France

${ }^{2}$ Centre de Recherches Pétrographiques et Géochimiques, Unité Mixte de Recherches CNRS \&

Université de Lorraine, F-54500 Vandoeuvre-lès-Nancy, France

${ }^{3}$ Peking University, Department of Energy \& Sciences, College of Engineering, Beijing 100871

${ }^{4}$ GEOMAR Helmholtz Centre for Ocean Research Kiel, Wischhofstr. 1-3, D-24148 Kiel, Germany

${ }^{5}$ IFREMER, Département Ressources physiques et Ecosystèmes de fond de Mer (REM), Unité des Recherches et Développements Technologiques, 29280 Plouzané, France

${ }^{6}$ Istanbul Teknik University, Faculty of Mines, EMCOL and Department of Geological Engineering, TR34469 Istanbul, Turkey

${ }^{7}$ Aix Marseille University, CEREGE, F-13545 Aix-En-Provence, France

* Corresponding author : Livio Ruffine, email address : livio.ruffine@ifremer.fr

\begin{abstract}
:
On continental margins, upward migration of fluids from various sources and various subsurface accumulations, through the sedimentary column to the seafloor, leads to the development of cold seeps where chemical compounds are discharged into the water column. MarsiteCruise was undertaken in November 2014 to investigate the dynamics of cold seeps characterized by vigorous gas emissions in the Sea of Marmara (SoM).
\end{abstract}

A previous paper published by Bourry et al. (2009) presented the gas geochemistry of three seeps sampled along three different segments in the SoM. Their findings showed that the seeps were sourced by three different reservoirs. In this paper, seventeen seeps were investigated to determine the gas sources, unravel reservoir contributions, and estimate their level of mixing. The molecular and stable isotope compositions of the gas compounds were determined to establish the empirical diagrams that usually allow to delineate source domains. The results provide insights into the complexities of source mixing within the sedimentary column of the SoM before emission of the gases into the water column. The seep gases originate from deep thermogenic or microbial hydrocarbon sources, or from a CO2-rich source. Microbial sources producing methane from primary methanogenesis have been identified in the Tekirdağ and the Çınarcık basins. In addition, six different thermogenic reservoirs or six different pathways of migration are responsible for the supply of gas to the seeps on the highs and in the western basin. Five of them are undergoing biodegradation followed by secondary methanogenesis, thereby providing additional sources of microbial methane to the seeps. Overall, the gases emitted by the 
seventeen seeps consist of variable mixtures of different components from two or three sources.

Keywords: abiotic CO2-source, gas bubbles, molecular and isotopic compositions, primary and secondary methanogenesis, Sea of Marmara, seeps, thermogenic gases 


\section{Introduction}

Intensive gas emissions are common and widespread processes in oceanic and continental marine basins. Amongst the areas on Earth where they have been densely observed, one can cite offshore Siberia (Shakhova et al., 2014), the Norwegian continental margin including the well-studied Hakon Mosby Mud Volcano (Gentz et al., 2014; Milkov, 2004; Sauer et al., 2015; Westbrook et al., 2009), the North Sea (Borges et al., 2016; McGinnis et al., 2011; von Deimling et al., 2011), the Black Sea (Klaucke et al., 2006; Roemer et al., 2012a), the Sea of Marmara (Dupré et al., 2012; Dupré et al., 2010a), the Aquitaine Shelf (Dupré et al., 2014; Ruffine et al., 2017), the Central Nile Deep-Sea Fan (Dupré et al., 2010b; Roemer et al., 2014a), the US Atlantic Margin (Skarke et al., 2014; Weinstein et al., 2016), the Gulf of Mexico (Bernard et al., 1976; Hu et al., 2012), the Santa Barbara Basin (Clark et al., 2010), the Hydrate Ridge (Haeckel et al., 2004; Milkov et al., 2005; Philip et al., 2016), the Makran continental margin (Roemer et al., 2012b), the South China Sea (Di et al., 2014; Huang et al., 2009), the Japan Sea (Aoyama et al., 2007), as well as offshore New Zealand (Greinert et al., 2010) and the Southern Ocean (Roemer et al., 2014b). Such phenomena occur either as dissolved or free gases, and they lead to the formation of specific sites called cold seeps (Hovland and Judd, 1988; Suess, 2014; Talukder, 2012). The number of discovered cold seeps has drastically increased over the last decades thank to the use of underwater vehicles for visual inspection of the ocean floor and the development of acoustic techniques that identify gas flares in the water mass (Bayrakci et al., 2014; Leblond et al., 2014). Seeps characterized by intensive gas emissions at the seafloor are the subject of a growing body of scientific studies with the aim to better understand their role in the global carbon cycle and to 
quantify their possible discharge into the atmosphere. In the hydrocarbon industry, natural gas emissions are regarded as a favorable exploration criterion for the presence of gas subsurface accumulations (also called reservoirs), which can potentially be reserves. In most cases, methane is the dominant component. Its concentration varies according to the gas source: it is usually far more significant in microbial gases than in thermogenic ones (Bernard et al., 1976; Claypool and Kaplan, 1974; Etiope, 2012), which are the two major methane sources encountered at cold seeps. Thermogenic methane results from the thermal decomposition of organic matter and is the main compound of many conventional natural gas reservoirs (Milkov, 2011). Thus, it is often associated with heavier hydrocarbons (Schoell, 1980; Schoell, 1983; Whiticar, 1994). Microbial methane is mainly produced either by reduction of carbon dioxide $\left(\mathrm{CO}_{2}\right)$ or methyl fermentation (Whiticar, 1999; Whiticar et al., 1986). Such processes are called primary methanogenesis. There is a second pathway for the production of methane called secondary methanogenesis. It results from the biodegradation of thermogenic hydrocarbons, especially propane but also other n-alkanes such as ethane, n-butane and npentane, which produces $\mathrm{CO}_{2}$ and the latter is reduced to methane (Dimitrakopoulos and Muehlenbachs, 1987; Etiope et al., 2009; Head et al., 2003; Jones et al., 2007; Milkov and Dzou, 2007; Milkov, 2010; Milkov, 2011; Pallasser, 2000). Secondary methanogenesis involves thermogenic hydrocarbons and occurs at the reservoir level or during secondary migration.

Besides the prevalence of methane, the emitted gases often results from asymmetric contributions of several sources that are reflected in their molecular and isotopic compositions.

That is how the isotopic composition of helium $\left({ }^{3} \mathrm{He} /{ }^{4} \mathrm{He}\right)$ provides a tool to identify abioticgas contributions from different regions of the mantle or from the continental crust, and, combined with the ${ }^{4} \mathrm{He} /{ }^{20} \mathrm{Ne}$ ratio, from the atmosphere (Graham, 2002).

The Sea of Marmara (SoM) is among the most promising places to study gas sources and mixing. This is because it has a moderate water depth $(<\sim 1250 \mathrm{~m}$ in its deepest basin), it incorporates part of the Thrace Basin -one of the most important thermogenic-hydrocarbon basin in Turkey- and also holds important reservoirs of microbial gas, and is characterized by a large number of hydrocarbon emission sites discharging gases into the water column (Bourry et al., 2009; Dupré et al., 2012; Gürgey et al., 2005; Hoşgörmez et al., 2005; Ruffine et al., 2012). Bourry et al. (2009) analyzed gas bubbles collected during the Marnaut cruise in 2007 (Henry, 2007) from three seeps located on the Western and Central highs, and in the Çınarcık Basin. They found that the gases were mainly of thermogenic origin on the highs 
whereas a microbial source supplies the sampled seeps in the basins. However, the three sampled seeps are not likely to be representative of the geochemical characteristics of the widespread gas emission sites revealed by Dupré et al. (2015) over the entire SoM.

This article focuses on the sources of gases emitted into the water column, the implications of different reservoirs and their level of mixing from seventeen seeps sampled along five faultsegments of the North Anatolian Fault in the SoM.

\section{Selection of seep locations}

The Sea of Marmara is located in Turkish territory (Fig. 1). It is an interior sea connected to the Mediterranean Sea to the west through the Darnadelle Strait, and to the Black Sea to the northeast via the Bosphorus Strait. The SoM is composed of three deep basins, which are from east to west the Tekirdağ Basin, the Central Basin and the Çınarcık Basin. The deep basins are separated by the Western and Central highs. The fault network in the SoM is relatively dense and belongs to the North Anatolian Fault (NAF) zone. The northern branch, the Main Marmara Fault (Le Pichon et al., 2001), is seismically the most active one, causing devastating earthquakes (Ambraseys, 2002; Ambraseys, 2000; Ambraseys and Jackson, 2000).

During MarsiteCruise, in November 2014 onboard the $R / V$ Pourquoi pas?, five ROV dives were performed along five selected seismically active segments of the NAF fault network where previous acoustic surveys showed evidence of gas emissions (Dupré et al., 2012; Ruffine et al., Submitted to this issue). These sites were previously visited during the Marnaut cruise (Fig. 2). Dive MRS-DV-592 (hereafter called DV1) was performed on the Central High, along the NAF, about $12 \mathrm{~km}$ south of the city of Istanbul. This segment has not ruptured since 1766 and there is a current debate on whether or not it is locked or creeping (Ergintav et al., 2014; Sakic et al., 2016; Schmittbuhl et al., 2016). Dive MRS-DV-593 (hereafter called DV2) was carried out on the Western High. This is the only site where gas hydrates have been collected so far in the SoM. It is characterized by a dormant mud volcano covered by carbonate pavements (Crémière et al., 2013; Crémiere et al., 2012). Dive MRSDV-594 (hereafter called DV3) allowed us to explore and sample seeps on a splay fault located on the western flank of the Tekirdağ Basin in the prolongation of the Ganos fault segment. The Ganos fault is known to have ruptured on land during the M=7.4 ŞarköyMürefte Earthquake in 1912 (Aksoy et al., 2010; Altinok et al., 2003), and evidence of mantle helium was found at the southern part of the fault (Burnard et al., 2012). Dive MRS-DV-595 
(hereafter called DV4) was undertaken at the southeast of the Tekirdağ Basin, along the lower slope of the Western High. Several small chimneys have been discovered in this area (Armijo et al., 2005; Burnard et al., 2012; Tryon et al., 2010; Zitter et al., 2008; Zitter et al., 2012). The last Dive MRS-DV-596 (hereafter called DV4) was performed in the southeastern Çınarcık Basin. It allowed us to revisit the sampled seep during the Marnaut cruise and the surrounding seeps.

\section{Data and methods}

Sampling of the gas seeps

During the exploration with the ROV Victor 6000, in situ research of gas emissions was based on visual inspection coupled with sonar guiding. The seeps were often composed of several gas streams close to each other, and the more vigorous stream was sampled by deploying our gas-bubble sampler PEGAZ (for PrElèvement de GAZ). This sampler was designed to collect gas bubbles and preserve the sample at the in situ pressure until its recovery (Lanteri and Bignon, 2007; Ruffine et al., 2017). Aliquots of gas were then subsampled at low pressure (24 bars) in $12-\mathrm{mL}$ pre-evacuated vials from Labco ${ }^{\circledR}$ by connecting the PEGAZ sampler to a custom-made gas transfer system (Charlou et al., 2004). The remaining gases were stored in containers of 100, 200 or $1000 \mathrm{~mL}$.

Gas geochemical analyses

The subsamples were analyzed to determine their molecular and isotopic compositions. Molecular composition analysis was carried out both on-board and at the Laboratoire des Cycles Géochimiques et ressources (LCG) at Ifremer. A gas chromatograph $\mu \mathrm{GC}$ R3000 from SRA equipped with a $\mu \mathrm{TCD}$ and a PoraPlot U capillary column was used on-board to determine nitrogen, oxygen, methane to hexane and carbon-dioxide concentrations. Hydrocarbons at low concentrations in the samples $(<1 \%$-mol $)$ were analyzed at the LCG using an Agilent 7890A gas chromatograph equipped with a $32 \mathrm{~m}, 0.32 \mathrm{~mm}$ Porapak Q column. The uncertainty in the measurements was of $\pm 2 \%$ for methane and carbon dioxide concentrations, and $\pm 4 \%$ for the heavier hydrocarbons.

The isotopic analyses were focused on the determination of the stable carbon $\left(\delta^{13} \mathrm{C}\right)$ and hydrogen $(\delta \mathrm{D})$ isotope ratios. The analyses were carried out at Isolab (The Netherlands) on a gas chromatograph-isotope ratio-mass spectrometers (GC-IR-MS). An Agilent $6890 \mathrm{~N}$ gas chromatograph interfaced with a Finigan Delta S IRMS and a Finigan GC-C II interface (Thermo) were used for the analysis of the stable carbon isotopes of methane and carbon 
dioxide. Separation from the GC was conducted with a $12 \mathrm{~m}$ long and $0.32 \mathrm{~mm}$ diameter molsieve column from Agilent. The minimum concentration required was of 25-50 ppm. Stable carbon isotopes of heavier hydrocarbons were analyzed on an Agilent 7890A gas chromatograph interfaced with a MAT 253 IRMS using a GC-Isolink or a Finigan GC-C III interface. The gas chromatograph was equipped with a $25 \mathrm{~m}$ long and $0.32 \mathrm{~mm}$ diameter Porabond-Q column from Agilent and an injection valve. In the case of low amounts of heavier hydrocarbons, such as for microbial gases, an additional cold trapping step was performed to pre-concentrate the compounds to be analyzed. $\delta \mathrm{D}$ measurements were made on an Agilent 7890A gas chromatograph interfaced with a MAT 253 IRMS and using a GCIsolink interface from Thermo. The GC was equipped with a $25 \mathrm{~m}$ long and $0.32 \mathrm{~mm}$ diameter molsieve column and an injection valve. For each sample, three runs of analyses were carried out and the isotopic values result from their average. For calibration purposes, the instruments were regularly checked against a calibration standard. The presented values are as part per thousand (\%) relative to the Vienna PeeDee Belemnite Standard (VPDB) and the Vienna Standard Mean Ocean Water (VSMOW) for $\delta^{13} \mathrm{C}$ and $\delta \mathrm{D}$, respectively. The uncertainties in the $\delta^{13} \mathrm{C}$ and $\delta \mathrm{D}$ measurements are $\pm 0.1-0.3 \%$ and $\pm 1 \%$, respectively.

The helium isotope measurements were made at the Centre de Recherches Pétrographiques et Géochimiques (CRPG) Nancy France, following the procedure described in Burnard et al. (2012). Briefly, aliquots of bubble gases were purified using a combination of cold traps and getters, and sequentially analyzed for He isotopes and abundances as well as $\mathrm{Ne}$ abundances in a double collector static mass spectrometer (Thermo SFT). The ${ }^{4} \mathrm{He} /{ }^{20} \mathrm{Ne}$ ratios trace the extent of contamination by atmospheric gases (Ozima and Podosek, 2002). Typically, ${ }^{4} \mathrm{He} /{ }^{20} \mathrm{Ne}$ is 0.32 in air, and $>1,000$ in the mantle. The data are expressed as Ra values, where $\mathrm{Ra}$ is the atmospheric He isotope ratio of $1.39 \times 10^{-6}$.

\section{Results}

The molecular and stable isotope compositions of the gases are listed in Tables 1 and 2. Overall, the molecular compositions of the sampled seeps vary widely, with values ranging between 2.01 and 99.79 mol. \% for methane, and 0.0873 and $97.6438 \mathrm{~mol}$ \% for carbon dioxide. Samples from the Central High, the southeastern flank of Tekirdağ Basin and the Çınarcık Basin are dry with more than 98 mol. \% of methane, whereas the amounts of heavier hydrocarbons are significantly high in Western High samples, which can therefore be classified as wet gases. Gas sampled from the western flank of Tekirdağ Basin are 
characterized by a high $\mathrm{CO}_{2}$ content at the southwestern part of the ROV track (Fig.1). The carbon $\left(\delta^{13} \mathrm{C}\right)$ and hydrogen $(\delta \mathrm{D})$ stable isotope compositions of methane range between -34 and $-66.1 \%$, and -253 and $-174 \%$, respectively. $\delta^{13} \mathrm{C}$ of $\mathrm{CO}_{2}$ is also very heterogeneous from one sample to another, with values ranging between -19.0 and $+28.4 \%$.

The helium isotopic ratios have been measured for several gas samples (Table 3). In a ${ }^{3} \mathrm{He} /{ }^{4} \mathrm{He}$ vs. ${ }^{4} \mathrm{He} /{ }^{20} \mathrm{Ne}$ diagram (Fig. 3), data plot in an area defined by mixing curves between (i) the atmosphere, or atmospheric gases dissolved in water, (ii) a ${ }^{3} \mathrm{He}$-rich mantle endmember, and (iii) a crustal end-member, rich in radiogenic ${ }^{4} \mathrm{He}$. Remarkably, for all samples not dominated by the atmospheric contamination, a mantle contribution is present, highlighting the role of large-scale fault system to permit mantle degassing (Kennedy et al., 1997). The samples MRS-DV03-PE01 and MRS-DV03-PE06 (Fig. 2) show the highest ${ }^{3} \mathrm{He} /{ }^{4} \mathrm{He}$ ratios recorded in the SoM, with values up to $5.25 \mathrm{Ra}$. These values are consistent with a contribution from the sub-continental lithospheric mantle (SCLM; 6.1 $\pm 0.9 \mathrm{Ra}$ (Gautheron and Moreira, 2002)). Similar high ${ }^{3} \mathrm{He} /{ }^{4} \mathrm{He}$ ratios were found in the same area by Burnard et al (2012).

\section{Discussion}

Gas sources

Molecular and isotopic compositions of gas components are used to determine their origin with well-known geochemical diagrams as shown in Fig. 4 (Milkov et al., 2005; Milkov, 2011; Schoell, 1980; Whiticar, 1999). Overall, the first three diagrams together show that except for the two samples from the Western High, the molecular and isotopic compositions of the seep gases fall within a domain corresponding to mixtures of thermogenic and microbial sources. While methane can be of either thermogenic or microbial origin, the heavier hydrocarbons (hereafter called $\mathrm{C}_{2+}$ ) originate from thermogenic sources. For clarity, the discussion on the gas sources is structured around each dive as they represent previously investigated sites (Burnard et al., 2012; Henry, 2007) except for the last two that are discussed together.

\section{Dive MRS-DV1 on Central High}

The molecular composition of our two sampled seeps are very similar to sample PG-1664 reported by Bourry et al. (2009). The samples PG-1664 and MRS-DV1-PE02 were collected at the same gas seep and separated by a distance of $\sim 12 \mathrm{~m}$ from each other. Therefore, it is not surprising that they have very similar molecular and isotopic compositions. This is especially 
the case for the $\delta^{13} \mathrm{C}$ of methane and carbon dioxide. Based on these $\delta^{13} \mathrm{C}$ values, Bourry et al. (2009) claimed that the gases originated from a thermogenic reservoir, and had partly undergone hydrocarbon biodegradation followed by secondary methanogenesis at the reservoir level or during its migration from the reservoir. This is in agreement with the diagrams presented in Fig. $4 \mathrm{a}, 4 \mathrm{c}$ and $4 \mathrm{~d}$, where the data fall within the mixing region. Fig. $4 \mathrm{~b}$ indicates that both methane and ethane are of thermogenic origin, and does not show any microbial contribution. This is not surprising as these diagrams were designed without incorporating data on methane generated by secondary methanogenesis but instead from carbon-dioxide reduction and methyl fermentation. However, Fig. 4d, derived from Milkov (2011), clearly shows the microbial contribution resulting from secondary methanogenesis. As mentioned previously, secondary methanogenesis is a biogeochemical process that reduces the ${ }^{13} \mathrm{C}$-depleted $\mathrm{CO}_{2}$ generated by the degradation of linear light hydrocarbons into ${ }^{13} \mathrm{C}$ depleted methane (Dimitrakopoulos and Muehlenbachs, 1987; Head et al., 2003; Jones et al., 2007; Pallasser, 2000). Here, propane is extremely enriched in ${ }^{13} \mathrm{C}$, and this is used as a proxy for identifying secondary methanogenesis.

The propane $\delta^{13} \mathrm{C}$ of the samples from MarsiteCruise is heavier than those from Marnaut cruise collected seven years earlier. This suggests that the hydrocarbon biodegradation is ongoing.

\section{Dive MRS-DV2 on Western High}

The seeps from the Western High are the wettest ones sampled so far, indicative of a large contribution from a deep-seated thermogenic source. As for the seeps on the Central High, it has been shown from previous studies that the seeps here emit gases resulting from a mixing of thermogenic and microbial sources, with the latter generated at reservoir level or during secondary migration (Bourry et al., 2009; Ruffine et al., 2012). Admixture of microbial methane from secondary methanogenesis is clearly shown in Fig. 4d. It is worth noticing that none of the first three diagrams from Fig. 4 reflects the source mixing, and this again highlights their limitations. Thus, one should always combine the interpretation of these diagrams with both the Milkov diagram (Fig. 4d) and a careful analysis of the isotopic compositions of $\mathrm{CO}_{2}$ and $\mathrm{C}_{2+}$ (Head et al., 2003; Waseda and Iwano, 2008). Although the isotopic compositions of our new samples are very similar to the one reported by Bourry et al. (2009) their molecular compositions are significantly different and are characterized by lower contents of methane and higher contents of $\mathrm{CO}_{2}$, though a distance of only $\sim 69 \mathrm{~m}$ separates MRS-DV2-PE01 from PG-1662. As mentioned previously, thermogenic gas hydrates are present in the sedimentary column on the Western High (Bourry et al., 2009; Ruffine et al., 
2012), and such differences in the molecular compositions of the three seeps are likely due to molecular fractionation caused by gas hydrate formation and dissociation (Milkov et al., 2004). Such a process does not affect the isotopic signatures of the gas components but alter their molecular compositions.

Dive MRS-DV3 at the western flank of Tekirdăg Basin

The gas sources supplying the seeps at this area have not been identified from previous cruises. From the molecular composition of sample MRS-DV3-PE03, it appears clearly that the seep is primarily supplied by a $\mathrm{CO}_{2}$-rich source as this compound accounts for more than $97 \%$-mol of the total gases. Moreover, it is likely that the $\mathrm{CO}_{2}$-rich source also supplies to a lesser extent the seep represented by sample MRS-DV3-PE02 as the amount of this compound is relatively high $(\sim 8 \%$-mol). The two seeps are separated by $\sim 728 \mathrm{~m}$. Thus, this distance corresponds to the lower estimate of the influence perimeter of the $\mathrm{CO}_{2}$-rich source. The He isotopic composition was not measured for this sample, but those from the nearby samples MRS-DV3-PE01 and MRS-DV3-PE06 show the highest ${ }^{3} \mathrm{He} /{ }^{4} \mathrm{He}$ values recorded so far for the whole area (Table 3), underpinning degassing of mantle gases there. The $\delta^{13} \mathrm{C}$ of carbon dioxide and methane for MRS-DV3-PE03 reflects respectively an inorganic and thermogenic source (Waseda and Iwano, 2008). However, Doğan et al. (2009) showed the occurrence of gas emission composed of soil $\mathrm{CO}_{2}$, characterized by depleted $\delta^{13} \mathrm{C}$ with mantle helium along a fault segment nearby. This $\mathrm{CO}_{2}$ source could partly supply our sampled seep, but cannot explain the enriched $\delta^{13} \mathrm{C}$ measured without admixture of another source (Dogan et al., 2009).

Mantle helium has also been sampled at this area (Burnard et al., 2012), and the contribution of abiotic mantle gases has been confirmed in the frame of MarsiteCruise (Table 3). Except for the methane, the two samples MRS-DV3-PE02 and MRS-DV3-PE03 have similar isotopic compositions for the $\mathrm{C}_{2+}$ fraction. Thus, the lighter methane $\delta^{13} \mathrm{C}$ measured for MRS-DV3PE02 indicates a contribution from a microbial source. Samples MRS-DV3-PE01 and MRSDV3-PE06 were taken at a tension gash on the seafloor at the site called Boris Bubbler (Géli et al., 2008; Henry, 2007; Tary et al., 2012) where the two most vigorous gas seeps were found (Ruffine et al., Submitted to this issue). The seeps were respectively called Chnikov and Boubouns, by the scientific team. They exhibit very similar molecular and isotopic compositions; except for the carbon dioxide, which is more significant and more enriched in ${ }^{13} \mathrm{C}$ for MRS-DV3-PE06. Both samples are characterized by ${ }^{13} \mathrm{C}$-enriched $\mathrm{n}$-butane and $\mathrm{n}$ pentane, and ${ }^{13} \mathrm{C}$-depleted methane. The isotopic signatures of all these four aforementioned 
components, methane, $\mathrm{CO}_{2}$, n-butane and n-pentane, are indicative of thermogenic gases having undergone hydrocarbon biodegradation followed by secondary methanogenesis. Interestingly, these two seeps have the highest He isotope ratios. Thus, the gases at these two vigorous seeps result from a mixture of thermogenic, microbial and abiotic gases. The deep abiotic source contributing to the gas supply is possibly a source of energy necessary for thermogenic gas generation in this area. Sample MRS-DV3-PE09 was taken in an area where a huge amount of oil droplets was seeping out at the seafloor (Ruffine et al., Submitted to this issue). Surprisingly it corresponds to the driest sample collected along the Ganos fault segment. The propane is extremely enriched in ${ }^{13} \mathrm{C}$ and this is indicative of biodegradation, whereas the $\delta^{13} \mathrm{C}$ of carbon dioxide is very light. These observations hold true for sample MRS-DV3-PE04, which exhibits the most ${ }^{13} \mathrm{C}$-enriched propane amongst all the visited seeps. Thus, it is likely that the seeps corresponding to samples MRS-DV3-PE04 and MRS-DV3PE09 are mixes of a thermogenic source with a microbial source from secondary methanogenesis. Their hydrocarbon isotopic signatures, especially for linear alkanes, are very different. This evidences two different reservoirs or two different migration pathways, which are also different from the thermogenic reservoirs supplying the two seeps represented by samples MRS-DV3-PE01 and MRS-DV3-PE06. Accordingly, at least four thermogenic gas reservoirs or migration pathways contribute to emissions along this $\sim 5-\mathrm{km}$-long fault segment (Table 4). They are sourcing the seeps represented by MRS-DV3-PE04, MRS-DV3-PE09, MRS-DV3-PE02 and MRS-DV3-PE03, and MRS-DV3-PE01 and MRS-DV3-PE06, respectively. Except for the reservoir sourcing the seep represented by samples MRS-DV3PE02 and MRS-DV3-PE03, all are undergoing hydrocarbon biodegradation followed by secondary methanogenesis. Thus, they are associated with secondary microbial methane. Besides, a mantle-derived $\mathrm{CO}_{2}$ and ${ }^{3} \mathrm{He}$ source supplies significant contribution for the seeps represented by MRS-DV3-PE01, MRS-DV3-PE02, MRS-DV3-PE06 and MRS-DV3-PE03, and a microbial source provides methane from primary methanogenesis to the seep represented by MRS-DV3-PE02. It may be worth noting that the microbial methane admixture becomes dominant when moving NE along the scarp (i.e. towards samples MRSDV3-PE4 and PE9). Deformation observed along the NW Tekirdağ scarp decreases towards the north as strain is distributed on two parallel systems of normal faults in the basin branching from the NW scarp (Grall et al., Submitted to this issue). The N Tekirdağ scarp is not presently active, but still expels gas. Assuming that microbial gases can be generated within the Quaternary sediments in the basin, there could be a relationship between fault activity and the channeling of fluid from the Thrace basin and the mantle. 
Dives MRS-DV4 at the southeastern flank of Tekirdăg Basin and MRS-DV5 in Çınarcık Basin

The molecular and isotopic compositions of methane clearly show that microbial gases are overwhelmingly present at these locations. This conclusion is well illustrated by Fig. 4b, 4c and $4 \mathrm{~d}$, and is in agreement with Bourry et al. (2009). The negative values of $\delta^{13} \mathrm{C}$ for $\mathrm{CO}_{2}$ together with the ${ }^{13} \mathrm{C}$-depleted $\mathrm{C}_{2+}$ do not indicate any hydrocarbon biodegradation followed by methane generation at reservoir level or during secondary migration of thermogenic hydrocarbons. Thus, the methane was generated from primary methanogenesis, and the presence of hydrocarbons heavier than ethane suggests a small thermogenic contribution in agreement with Fig. 4b.

\section{Overprinting of gas-to-source rock correlations by secondary alteration processes}

In the previous section, we have shown that most of the seeps emit gases which are mixes of thermogenic gases, primary and secondary microbial gases, and abiotic mantle-derived gases. Our results also show that hydrocarbon biodegradation followed by secondary methanogenesis is widespread on the Central and Western highs, as well as at the northwestern flank of the Tekirdağ Basin. It is important to emphasize that such processes have not been observed for any of the 11 onshore natural-gas fields investigated in previous studies (Gürgey et al., 2005; Hoşgörmez and Yalçin, 2005; Hoşgörmez et al., 2005).

These two post-genetic alterations can considerably change the isotopic signature of the gases expelled from the source rock. Berner and Faber (1996) have proposed an empirical model to link the maturity and types of organic matter of source rock with the carbon isotope signature of methane, ethane and propane (Fig. 5a and 5b). The application of such a model to our sample clearly highlights the implication of hydrocarbon biodegradation and secondary methanogenesis in modifying original methane and propane isotopic signatures. Thus, when using the $\delta^{13} \mathrm{C}$ signature of methane and ethane (Fig. 5a), only the $\mathrm{CO}_{2}$-rich sample MRSDV3-PE03 falls in between the two maturity curves characterizing marine (type II) and terrestrial (type III) kerogens, with a maturity of $\sim 1.7$ (Berner and Faber, 1988; Berner and Faber, 1996). This conclusion is supported by Fig. 5b, where the same sample is located at the cross section of type II and type III kerogen curves. Moreover, the hydrocarbons making up sample MRS-DV3-PE03 have the same isotopic signatures and very similar molecular compositions as the Kuzey-Marmara natural gas field (Gürgey et al., 2005; Hoşgörmez et al., 2005). Thus, we suggests that the seep represented by sample MRS-DV3-PE03 partly expresses a natural leakage of this natural gas-producing field. For the other samples, the 
depletion in methane $\delta^{13} \mathrm{C}$ due to admixture of microbial gases and the enrichment of propane $\delta^{13} \mathrm{C}$ due to hydrocarbon biodegradation overprinted the gas original-isotopic signature.

\section{Delineation of sources and reservoirs, and estimation of their level of mixing}

At the western flank of the Tekirdağ Basin, an abiotic $\mathrm{CO}_{2}$-rich source, a primary microbial gas source and four thermogenic reservoirs or migration pathways for which three are associated with secondary microbial gases have been identified. We also confirmed, in agreement with Bourry et al. (2009), that the two highs are characterized by emissions of gases that are primarily of thermogenic origin, but with an admixture of microbial gases from secondary methanogenesis. However, their molecular and isotopic compositions clearly show that the seeps from the two highs are supplied from two distinct subsurface accumulations. Moreover, on the Central High, sample MRS-DV1-PE03 is characterized by lighter methane $\delta^{13} \mathrm{C}$ and heavier carbon-dioxide $\delta^{13} \mathrm{C}$ compared to the two other samples (Table 2). These differences suggest either a more important admixture of microbial gases or an isotopic fractionation during migration due to gas diffusion (Prinzhofer and Pernaton, 1997). Because gas ebullition is the dominant transport process at gas seeps, we believe that different extents of biodegradation followed by secondary methanogenesis is the more plausible explanation for the difference in $\delta^{13} \mathrm{C}$ for methane, and this may be indicative of two different reservoirs or migration pathways.

In an attempt to further unravel the gas sources, differentiate reservoirs or migration pathways, and estimate their level of mixing, we applied the diagrams proposed by Chung (Chung et al., 1988), and Prinzhofer and Pernaton (Prinzhofer and Pernaton, 1997) to our gas samples. The former expresses the $\delta^{13} \mathrm{C}$ of the hydrocarbon components as a function of their reciprocal number of carbon atoms for the hydrocarbons (Fig. 6), and the latter represents the $\delta^{13} \mathrm{C}$ of methane as a function of the ethane-to-methane ratio (Fig. 7). These diagrams are usually used to identify pristine natural gas, source or reservoir mixing, as well as possible diffusion-causing isotopic fractionation. The $\mathrm{CO}_{2}$-rich sample MRS-DV3-PE03 from the western flank of the Tekirdağ Basin is the only one that leads to a linear profile when applying the Chung diagram. Such a profile is indicative of a pristine thermogenic natural gas (Fig. 6), as supported by the maturity diagrams (Fig. 5). Thus, this sample is a mixture of a $\mathrm{CO}_{2}$-rich source with a pristine thermogenic source. In addition to its connection to the $\mathrm{CO}_{2}$ rich source, sample MRS-DV3-PE02 contains both thermogenic and microbial methane, and does not show evidence of any significant hydrocarbon biodegradation (Fig. 6). Therefore, the 
major microbial gas contribution likely originates from a methane source generated from primary methanogenesis.

Based on the approach of Prinzhofer and Pernaton, we drew a mixing line using the methane $\delta^{13} \mathrm{C}$ values of MRS-DV3-PE03 and MRS-DV4-PE02 as thermogenic and microbial endmember, respectively (Fig. 7). We voluntarily took sample MRS-DV4-PE02 as microbial end-member even if it does not present the lightermethane $\delta^{13} \mathrm{C}$. The reason is that it is more representative of the $\delta^{13} \mathrm{C}$ of our measured dataset for microbial methane. It also provides a better mixing correlation, and its $\delta^{13} \mathrm{C}$ value is close to the value of $-61.48 \%$ calculated by Gurgey et al. (2005). Microbial gas-dominant samples with lighter methane $\delta^{13} \mathrm{C}$ have likely undergone diffusion-driven fractionation during their migration (Prinzhofer and Pernaton, 1997). Four samples MRS-DV2-PE02, MRS-DV3-PE02, MRS-DV3-PE03 and MRS-DV4PE02 fall well on the mixing line of these two sources (Fig. 6), and three other samples MRSDV3-PE01, MRS-DV3-PE06, MRS-DV5-PE04 are very close. Thus, by applying the equations below, it becomes possible to estimate the contribution of each gas source for these samples:

$$
\begin{aligned}
& \mathrm{TC}=\left(\delta^{13} \mathrm{C}_{\text {sample }}-\delta^{13} \mathrm{C}_{\mathrm{MC}}\right) /\left(\delta^{13} \mathrm{C}_{\mathrm{TC}}-\delta^{13} \mathrm{C}_{\mathrm{MC}}\right) \\
& \mathrm{MC}=\left(\delta^{13} \mathrm{C}_{\text {sample }}-\delta^{13} \mathrm{C}_{\mathrm{TC}}\right) /\left(\delta^{13} \mathrm{C}_{\mathrm{BC}}-\delta^{13} \mathrm{C}_{\mathrm{TC}}\right)
\end{aligned}
$$

Table 4 summarizes the estimated level of mixing between the identified gas sources. The seeps that are located on the highs and at the western flank of the Tekirdağ Basin are dominantly composed of thermogenic gases. The $\mathrm{CO}_{2}$-rich source contributes to $97.6 \%$-mol of the gas seep represented by sample MRS-DV3-PE03 from the western flank of the Tekirdağ Basin, the remaining being a pristine natural gas. The seep related to sample MRSDV3-PE02 is composed of around $7 \%$ of mantle $\mathrm{CO}_{2}, 68 \%$ of microbial methane from primary methanogenesis and $25 \%$-mol of pristine thermogenic gases (Table 4). The samples collected from the fault segments located at the southeastern flank of the Tekirdağ Basin and in the Çınarcık Basin come from gas seeps containing at least $94 \%$-mol of microbial methane generated from primary methanogenesis. Although aligned with the mixing line, sample MRS-DV2-PE02 from the Western High is characterized by a lighter methane $\delta^{13} \mathrm{C}$ compared to the value of $-34.0 \%$ measured for the pristine gas and a ${ }^{13} \mathrm{C}$-enriched carbon dioxide, which indicates a biodegradation of hydrocarbons followed by secondary methanogenesis. A high $\delta^{13} \mathrm{C}$ was also reported for the carbonate crust sampled on the mud volcanoes (Cagatay et al., Accepted for this issue; Crémiere et al., 2012). Because the methane $\delta^{13} \mathrm{C}$ of this sample is 
similar to the two others collected at this area, our best explanation is that the $\mathrm{C} 2 / \mathrm{C} 1$ ratio is controlled by hydrate formation and dissociation. Nevertheless, its isotopic composition indicates a moderate biodegradation, and a linear extrapolation from the ethane and n-butane $\delta^{13} \mathrm{C}$ to the ordinate axis on the Chung diagram leads to a modeled methane $\delta^{13} \mathrm{C}$ of $\sim-34 \%$. The latter value corresponds to the value of the pristine methane. Thus, the calculated microbial methane contribution is of $34 \%$ for sample MRS-DV2-PE02. The same mixing level would be expected for sample MRS-DV2-PE01. The close vicinity of the southeastern Tekirdağ Basin samples MRS-DV3-PE01 and MRS-DV3-PE06 with the mixing line suggests an admixture of microbial methane with an isotopic signature close to $-63.8 \%$. Based on this assumption, the thermogenic methane contribution of these two samples is of $\sim 39 \%$. The other samples are far from the mixing line. They contain both thermogenic and secondary microbial methane. The fact that they fall far from the mixing line suggests either different isotopic signatures for the end-members, or the occurrence of other alteration processes which overprint the source mixing.

\section{Conclusion}

The gases emitted at the seafloor in the Sea of Marmara result from the mixing of two or three sources at variable levels of mixing. While the $C_{2+}$ fraction is always of thermogenic origin, the methane constituting these gases is of either thermogenic or microbial source. Moreover, the microbial methane generation involves two different pathways, which are either primary or secondary methanogenesis. Strong influences of thermogenic sources are observed on the highs and at the western flank of the Tekirdağ Basin, and this study revealed that several thermogenic-gas reservoirs or migration pathways are involved. Moreover, amongst the thermogenic-gas reservoirs supplying the seeps, only one is not undergoing hydrocarbon biodegradation followed by secondary methanogenesis. Thus, the latter processes seem to be widespread within the thermogenic-gas reservoirs or during the secondary migration of gases in the SoM. A $\mathrm{CO}_{2}$-rich source was also discovered at the western flank of the Tekirdag Basin, and its isotopic signature provides evidence for a mantle origin. Thus, the Ganos fault segment on which the seeps are located act as a direct connection between the seafloor and the mantle. Both the Tekirdağ and Çınarcık basins hold primary microbial gas reservoirs that supply the seeps at these locations. There is a limited contribution of thermogenic sources in the Çınarcık Basin gas seeps. 
Agreement between both molecular and isotopic compositions of three seeps sampled with a time interval of seven years is very good except for the sample collected on the Western High, which indicates only a steady isotopic composition of the reservoir gases over this time scale. On the Western High, the difference between the two sampling rounds is due to the formation and dissociation of complex gas hydrates, which fractionate the migrating gases by preferential molecular trapping.

There is a large number of seeps for which the gas source has not been investigated, and this calls for a more intensive gas sampling campaign in the Sea of Marmara. An issue of primary importance is to quantify gas discharges into the water column together with methane oxidation in the sedimentary column to provide an estimate of the amount of gases released from natural leaking of reservoirs in the Sea of Marmara.

\section{Acknowledgements}

We thank the captain and his crew on-board the RV Pourquoi pas? as well as the team of the ROV Victor-6000 crew for their technical support and advice. We also thank Alison Chalm for the final proofreading of the manuscript. Financial support was provided by the European programme «MARsite», under the call ENV.2012.6.4-2: "Long-term monitoring experiment in geologically active regions of Europe prone to natural hazards: the Supersite concept". This work was also supported by the "Laboratoire d'Excellence" LabexMER (ANR-10-LABX-19) through the projects MicroGaMa and MISS Marmara, co-funded by a grant from the French government under the program "Investissements d'Avenir".

\section{Reference}

Aksoy, M.E., Meghraoui, M., Vallee, M., Cakir, Z., 2010. Rupture characteristics of the AD 1912 Murefte (Ganos) earthquake segment of the North Anatolian fault (western Turkey). Geology 38, 991-994.

Altinok, Y., Alpar, B., Yaltirak, C., 2003. Sarkoy-Murefte 1912 Earthquake's Tsunami, extension of the associated faulting in the Marmara Sea, Turkey. Journal of Seismology 7, 329-346.

Ambraseys, N., 2002. The seismic activity of the Marmara Sea region over the last 2000 years. Bulletin of the Seismological Society of America 92, 1-18.

Ambraseys, N.N., 2000. The seismicity of the Marmara Sea area 1800-1899. Journal of Earthquake Engineering 4, 377-401.

Ambraseys, N.N., Jackson, J.A., 2000. Seismicity of the Sea of Marmara (Turkey) since 1500. Geophysical Journal International 141, F1-F6. 
Aoyama, C., Matsumoto, R., Hiruta, A., Ishizaki, O., Machiyama, H., NumanAmi, H., Hiromatsu, M., Snyder, G., leee, 2007. Acoustical surveys of Methane plumes using the quantitative echo sounder in Japan Sea.

Armijo, R., Pondard, N., Meyer, B., Ucarkus, G., de Lepinay, B.M., Malavieille, J., Dominguez, S., Gutscher, M.A., Schmidt, S., Beck, C., Cagatay, N., Cakir, Z., Imren, C., Eris, K., Natalin, B., Ozalaybey, S., Tolun, L., Lefevre, I., Seeber, L., Gasperini, L., Rangin, C., Emre, O., Sarikavak, K., 2005. Submarine fault scarps in the Sea of Marmara pull-apart (North Anatolian Fault): Implications for seismic hazard in Istanbul. Geochemistry Geophysics Geosystems 6.

Bayrakci, G., Scalabrin, C., Dupre, S., Leblond, I., Tary, J.B., Lanteri, N., Augustin, J.M., Berger, L., Cros, E., Ogor, A., Tsabaris, C., Lescanne, M., Geli, L., 2014. Acoustic monitoring of gas emissions from the seafloor. Part II: a case study from the Sea of Marmara. Marine Geophysical Research 35, 211-229.

Bernard, B.B., Brooks, J.M., Sackett, W.M., 1976. Natural-gas seepage in the Gulf of Mexico. Earth and Planetary Science Letters 31, 48-54.

Berner, U., Faber, E., 1988. Maturity related mixing model for methane, ethane and propane, based on carbon isotopes. Organic Geochemistry 13, 67-72.

Berner, U., Faber, E., 1996. Empirical carbon isotope/maturity relationships for gases from algal kerogens and terrigenous organic matter, based on dry, open-system pyrolysis. Organic Geochemistry 24, 947-955.

Borges, A.V., Champenois, W., Gypens, N., Delille, B., Harlay, J., 2016. Massive marine methane emissions from near-shore shallow coastal areas. Scientific Reports 6.

Bourry, C., Chazallon, B., Charlou, J.L., Donval, J.P., Ruffine, L., Henry, P., Geli, L., Cagatay, M.N., Inan, S., Moreau, M., 2009. Free gas and gas hydrates from the Sea of Marmara, Turkey Chemical and structural characterization. Chemical Geology 264, 197-206.

Burnard, P., Bourlange, S., Henry, P., Geli, L., Tryon, M., Sengör, A., Özeren, M., Çagatay, M., 2012. Constraints on fluid origins and migration velocities along the Marmara Main Fault (Sea of Marmara, Turkey) using helium isotopes. Earth and Planetary Science Letters 341, 68-78.

Cagatay, M.N., Yıldız, G., Bayon, G., Ruffine, L., Henry, P., Accepted for this issue. Seafloor authigenic carbonate crusts along the submerged part of North Anatolian Fault in the Sea of Marmara: Mineralogy, geochemistry, textures and genesis Deep-Sea Research Part II: Topical Studies in Oceanography.

Charlou, J., Donval, J., Fouquet, Y., Ondreas, H., Knoery, J., Cochonat, P., Levache, D., Poirier, Y., JeanBaptiste, P., Fourre, E., 2004. Physical and chemical characterization of gas hydrates and associated methane plumes in the Congo-Angola Basin. Chemical Geology 205, 405-425.

Chung, H., Gormly, J., Squires, R., 1988. Origin of gaseous hydrocarbons in subsurface environments: theoretical considerations of carbon isotope distribution. Chemical Geology 71, 97-104.

Clark, J.F., Washburn, L., Emery, K.S., 2010. Variability of gas composition and flux intensity in natural marine hydrocarbon seeps (vol 30, 379, 2010). Geo-Marine Letters 30, 389-389.

Claypool, G.E., Kaplan, I.R., 1974. The origin and distribution of methane in marine sediments. In: Kaplan. I. R. (Eds.) Natural gases in marine sediments: New York, Plenum Press., 99-139.

Crémière, A., Bayon, G., Ponzevera, E., Pierre, C., 2013. Paleo-environmental controls on cold seep carbonate authigenesis in the Sea of Marmara. Earth and Planetary Science Letters 376, 200-211.

Crémiere, A., Pierre, C., Blanc-Valleron, M.-M., Zitter, T., Cagatay, M.N., Henry, P., 2012. Methanederived authigenic carbonates along the North Anatolian fault system in the Sea of Marmara (Turkey). Deep-Sea Research Part I-Oceanographic Research Papers 66, 114-130.

Di, P.F., Feng, D., Chen, D.F., 2014. In-situ and on-line measurement of gas flux at a hydrocarbon seep from the northern South China Sea. Continental Shelf Research 81, 80-87.

Dimitrakopoulos, R., Muehlenbachs, K., 1987. Biodegradation of petroleum as a source of 13 Cenriched carbon dioxide in the formation of carbonate cement. Chemical Geology 65, 283-291.

Dogan, T., Sumino, H., Nagao, K., Notsu, K., Tuncer, M.K., Celik, C., 2009. Adjacent releases of mantle helium and soil CO2 from active faults: Observations from the Marmara region of the North Anatolian Fault zone, Turkey. Geochemistry Geophysics Geosystems 10. 
Dupré, S., Berger, L., Le Bouffant, N., Scalabrin, C., Bourillet, J.-F., 2014. Fluid emissions at the Aquitaine Shelf (Bay of Biscay, France): A biogenic origin or the expression of hydrocarbon leakage? Continental Shelf Research 88, 24-33.

Dupré, S., Scalabrin, C., Géli, L., Henry, P., Grall, C., Çagatay, N., Imren, C., Team, a.t.M.S.P., 2012. Widespread gas emissions in the Sea of Marmara, results from systematic ship-borne multibeam echosounder water column imageries. 11th International Conference of Gas in Marine Sediments Nice.

Dupré, S., Scalabrin, C., Géli, L., Henry, P., Grall, C., Tary, J., Cagatay, M., Imren, C., 2010a. The MARMESONET Scientific Party Team (2010b) Widespread gas emissions in the Sea of Marmara in relation with the tectonic and sedimentary environments: results from shipborne multibeam echosounder water column imagery (MARMESONET expedition, 2009). Eur Geosci Union Gen Assem $12,9429$.

Dupré, S., Woodside, J., Klaucke, I., Mascle, J., Foucher, J.-P., 2010b. Widespread active seepage activity on the Nile Deep Sea Fan (offshore Egypt) revealed by high-definition geophysical imagery. Marine Geology 275, 1-19.

Ergintav, S., Reilinger, R.E., Cakmak, R., Floyd, M., Cakir, Z., Dogan, U., King, R.W., McClusky, S., Ozener, H., 2014. Istanbul's earthquake hot spots: Geodetic constraints on strain accumulation along faults in the Marmara seismic gap. Geophysical Research Letters 41, 5783-5788.

Etiope, G., 2012. CLIMATE SCIENCE Methane uncovered. Nature Geoscience 5, 373-374.

Etiope, G., Feyzullayev, A., Milkov, A.V., Waseda, A., Mizobe, K., Sun, C.H., 2009. Evidence of subsurface anaerobic biodegradation of hydrocarbons and potential secondary methanogenesis in terrestrial mud volcanoes. Marine and Petroleum Geology 26, 1692-1703.

Gautheron, C., Moreira, M., 2002. Helium signature of the subcontinental lithospheric mantle. Earth and Planetary Science Letters 199, 39-47.

Géli, L., Henry, P., Zitter, T., Dupré, S., Tryon, M., Çagatay, M., de Lépinay, B., Le Pichon, X., engör, A., Görür, N., 2008. Gas emissions and active tectonics within the submerged section of the North Anatolian Fault zone in the Sea of Marmara. Earth and Planetary Science Letters 274, 34-39.

Gentz, T., Damm, E., von Deimling, J.S., Mau, S., McGinnis, D.F., Schluter, M., 2014. A water column study of methane around gas flares located at the West Spitsbergen continental margin. Continental Shelf Research 72, 107-118.

Graham, D.W., 2002. Noble gas isotope geochemistry of mid-ocean ridge and ocean island basalts: Characterization of mantle source reservoirs. Reviews in mineralogy and geochemistry 47, 247-317.

Grall, C., Henry, P., Zitter, A.C.T., Dupré, S., Géli, L., Scalabrin, C., Sengor, A.M.C., Çağatay, M.N., Cifci, G., Submitted to this issue. Gas updip migration in an active tectonic basin: Role of fault damaging at shallow depth and sedimentation, the example of the Sea of Marmara. Deep-Sea Research Part II: Topical Studies in Oceanography.

Greinert, J., Lewis, K.B., Bialas, J., Pecher, I.A., Rowden, A., Bowden, D.A., De Batist, M., Linke, P., 2010. Methane seepage along the Hikurangi Margin, New Zealand: Overview of studies in 2006 and 2007 and new evidence from visual, bathymetric and hydroacoustic investigations. Marine Geology $272,6-25$.

Gürgey, K., Philp, R., Clayton, C., Emiro lu, H., Siyako, M., 2005. Geochemical and isotopic approach to maturity/source/mixing estimations for natural gas and associated condensates in the Thrace Basin, NW Turkey. Applied Geochemistry 20, 2017-2037.

Haeckel, M., Suess, E., Wallmann, K., Rickert, D., 2004. Rising methane gas bubbles form massive hydrate layers at the seafloor. Geochimica et Cosmochimica Acta 68, 4335-4345.

Head, I., Jones, D., Larter, S., 2003. Biological activity in the deep subsurface and the origin of heavy oil. Nature 426, 344-352.

Henry, P., 2007. Marnut cruise report.

Hoşgörmez, H., Yalçin, M., 2005. Gas-source rock correlation in Thrace basin, Turkey. Marine and Petroleum Geology 22, 901-916. 
Hoşgörmez, H., Yalçin, M., Cramer, B., Gerling, P., Mann, U., 2005. Molecular and isotopic composition of gas occurrences in the Thrace basin (Turkey): origin of the gases and characteristics of possible source rocks. Chemical Geology 214, 179-191.

Hovland, M., Judd, A., 1988. Seabed pockmarks and seepages: impact on geology, biology, and the marine environment. Graham \& Trotman.

Hu, L., Yvon-Lewis, S.A., Kessler, J.D., MacDonald, I.R., 2012. Methane fluxes to the atmosphere from deepwater hydrocarbon seeps in the northern Gulf of Mexico. Journal of Geophysical ResearchOceans 117.

Huang, B.J., Xiao, X.M., Li, X.S., Cai, D.S., 2009. Spatial distribution and geochemistry of the nearshore gas seepages and their implications to natural gas migration in the Yinggehai Basin, offshore South China Sea. Marine and Petroleum Geology 26, 928-935.

Jones, D., Head, I., Gray, N., Adams, J., Rowan, A., Aitken, C., Bennett, B., Huang, H., Brown, A., Bowler, B., 2007. Crude-oil biodegradation via methanogenesis in subsurface petroleum reservoirs. Nature 451, 176-180.

Kennedy, B., Kharaka, Y., Evans, W.C., Ellwood, A., DePaolo, D., Thordsen, J., Ambats, G., Mariner, R., 1997. Mantle fluids in the San Andreas fault system, California. Science 278, 1278-1281.

Klaucke, I., Sahling, H., Weinrebe, W., Blinova, V., Bürk, D., Lursmanashvili, N., Bohrmann, G., 2006. Acoustic investigation of cold seeps offshore Georgia, eastern Black Sea. Marine Geology 231, 51-67. Lanteri, N., Bignon, L., 2007. Device for taking pressurized samples. European Patent WO/2007/128891 www.wipo.int/patentscope/search/fr/WO2007128891.

Leblond, I., Scalabrin, C., Berger, L., 2014. Acoustic monitoring of gas emissions from the seafloor. Part I: quantifying the volumetric flow of bubbles. Marine Geophysical Research 35, 191-210.

McGinnis, D.F., Schmidt, M., DelSontro, T., Themann, S., Rovelli, L., Reitz, A., Linke, P., 2011. Discovery of a natural CO2 seep in the German North Sea: Implications for shallow dissolved gas and seep detection. Journal of Geophysical Research-Oceans 116.

Milkov, A., Claypool, G., Lee, Y., Sassen, R., 2005. Gas hydrate systems at Hydrate Ridge offshore Oregon inferred from molecular and isotopic properties of hydrate-bound and void gases. Geochimica et Cosmochimica Acta 69, 1007-1026.

Milkov, A., Dzou, L., 2007. Geochemical evidence of secondary microbial methane from very slight biodegradation of undersaturated oils in a deep hot reservoir. Geology 35, 455.

Milkov, A.V., 2004. Global estimates of hydrate-bound gas in marine sediments: how much is really out there? Earth-Science Reviews 66, 183-197.

Milkov, A.V., 2010. Methanogenic biodegradation of petroleum in the West Siberian Basin (Russia): Significance for formation of giant Cenomanian gas pools. Aapg Bulletin 94, 1485-1541.

Milkov, A.V., 2011. Worldwide distribution and significance of secondary microbial methane formed during petroleum biodegradation in conventional reservoirs. Organic Geochemistry 42, 184-207.

Milkov, A.V., Claypool, G.E., Lee, Y.J., Torres, M.E., Borowski, W.S., Tomaru, H., Sassen, R., Long, P.E., Party, O.D.P.L.S., 2004. Ethane enrichment and propane depletion in subsurface gases indicate gas hydrate occurrence in marine sediments at southern Hydrate Ridge offshore Oregon. Organic Geochemistry 35, 1067-1080.

Ozima, M., Podosek, F.A., 2002. Noble gas geochemistry. Cambridge University Press.

Pallasser, R., 2000. Recognising biodegradation in gas/oil accumulations through the $13 \mathrm{C}$ compositions of gas components. Organic Geochemistry 31, 1363-1373.

Philip, B.T., Denny, A.R., Solomon, E.A., Kelley, D.S., 2016. Time-series measurements of bubble plume variability and water column methane distribution above Southern Hydrate Ridge, Oregon. Geochemistry Geophysics Geosystems 17, 1182-1196.

Prinzhofer, A., Pernaton, E., 1997. Isotopically light methane in natural gas: bacterial imprint or diffusive fractionation? Chemical Geology 142, 193-200.

Roemer, M., Sahling, H., Pape, T., Bahr, A., Feseker, T., Wintersteller, P., Bohrmann, G., 2012a. Geological control and magnitude of methane ebullition from a high-flux seep area in the Black Seathe Kerch seep area. Marine Geology 319, 57-74. 
Roemer, M., Sahling, H., Pape, T., Bohrmann, G., Spiess, V., 2012b. Quantification of gas bubble emissions from submarine hydrocarbon seeps at the Makran continental margin (offshore Pakistan). Journal of Geophysical Research-Oceans 117.

Roemer, M., Sahling, H., Pape, T., Ferreira, C.d.S., Wenzhoefer, F., Boetius, A., Bohrmann, G., 2014a. Methane fluxes and carbonate deposits at a cold seep area of the Central Nile Deep Sea Fan, Eastern Mediterranean Sea. Marine Geology 347, 27-42.

Roemer, M., Torres, M., Kasten, S., Kuhn, G., Graham, A.G.C., Mau, S., Little, C.T.S., Linse, K., Pape, T., Gepraegs, P., Fischer, D., Wintersteller, P., Marcon, Y., Rethemeyer, J., Bohrmann, G., Shipboard Sci Party, A.-X., 2014b. First evidence of widespread active methane seepage in the Southern Ocean, off the sub-Antarctic island of South Georgia. Earth and Planetary Science Letters 403, 166-177.

Ruffine, L., Donval, J.P., Croguennec, C., Bignon, L., Birot, D., Battani, A., Bayon, G., Caprais, J.C., Lanteri, N., Levache, D., Dupre, S., 2017. Gas Seepage along the Edge of the Aquitaine Shelf (France): Origin and Local Fluxes. Geofluids.

Ruffine, L., Fandino, O., Etoubleau, J., Chéron, S., Donval, J.P., Germain, Y., Ponzevera, E., Guyader, V., Dennielou, B., Etiope, G., Gasperini, L., Bortoluzzi, G., Henry, P., Grall, C., Çagatay, M.N., Charlou, J.L., Géli, L., 2012. Geochemical dynamics of the natural-gas hydrate system in the Sea of Marmara, offshore Turkey. Advances in Natural Gas Technology ISBN 978-953-51-0507-7, pp. 29-56.

Ruffine, L., Ondreas, H., Scalabrin, C., Rinnert, E., P., D.J., Croguennec, C., Ponzevera, E., Alix, A.S., Germain, Y., Birot, D., Bignon, L., Etoubleau, J., Teichert, B., Knoery, J., Lesongeur, F., Thomas, B., Roubi, A., Legoix, L., Blanc-Valleron, M.M., Burnard, P., Chevalier, N., Olgunh, K.N., Lu, H., Özaksoyj, V., Perchock, J., Podeur, C., Tarditi, C., Özbekij, E., V, G., Marsset, B., Dupré, S., Fontanier, C., Yang, H., Dissard, D., Chéron, S., Brandily, C., C., C.J., Strauss, H., Pierre, C., Cagatay, M.N., Marty, B., Henry, P., Géli, L., Submitted to this issue. Multidisciplinary investigation on cold seeps with vigorous gas emissions in the Sea of Marmara (Marsite Cruise): Strategy for site detection and sampling, scientific outcome and research roadmap. Deep-Sea Research Part II: Topical Studies in Oceanography This issue.

Sakic, P., Piete, H., Ballu, V., Royer, J.Y., Kopp, H., Lange, D., Petersen, F., Ouml;zeren, M.S., Ergintav, S., Geli, L., Henry, P., Deschamps, A., 2016. No significant steady state surface creep along the North Anatolian Fault offshore Istanbul: Results of 6months of seafloor acoustic ranging. Geophysical Research Letters 43, 6817-6825.

Sauer, S., Knies, J., Lepland, A., Chand, S., Eichinger, F., Schubert, C.J., 2015. Hydrocarbon sources of cold seeps off the Vesteralen coast, northern Norway. Chemical Geology 417, 371-382.

Schmittbuhl, J., Karabulut, H., Lengline, O., Bouchon, M., 2016. Seismicity distribution and locking depth along the Main Marmara Fault, Turkey. Geochemistry Geophysics Geosystems 17, 954-965.

Schoell, M., 1980. The hydrogen and carbon isotopic composition of methane from natural gases of various origins. Geochimica et Cosmochimica Acta 44, 649-661.

Schoell, M., 1983. Genetic characterization of natural gases. Aapg Bulletin 67, 2225-2238.

Shakhova, N., Semiletov, I., Leifer, I., Sergienko, V., Salyuk, A., Kosmach, D., Chernykh, D., Stubbs, C., Nicolsky, D., Tumskoy, V., Gustafsson, O., 2014. Ebullition and storm-induced methane release from the East Siberian Arctic Shelf. Nature Geoscience 7, 64-70.

Skarke, A., Ruppel, C., Kodis, M., Brothers, D., Lobecker, E., 2014. Widespread methane leakage from the sea floor on the northern US Atlantic margin. Nature Geoscience 7, 657-661.

Suess, E., 2014. Marine cold seeps and their manifestations: geological control, biogeochemical criteria and environmental conditions. International Journal of Earth Sciences 103, 1889-1916.

Talukder, A.R., 2012. Review of submarine cold seep plumbing systems: leakage to seepage and venting. Terra Nova 24, 255-272.

Tary, J.B., Geli, L., Guennou, C., Henry, P., Sultan, N., Cagatay, N., Vidal, V., 2012. Microevents produced by gas migration and expulsion at the seabed: a study based on sea bottom recordings from the Sea of Marmara. Geophysical Journal International 190, 993-1007.

Tryon, M.D., Henry, P., Cagatay, M.N., Zitter, T.A.C., Geli, L., Gasperini, L., Burnard, P., Bourlange, S., Grall, C., 2010. Pore fluid chemistry of the North Anatolian Fault Zone in the Sea of Marmara: A diversity of sources and processes. Geochemistry Geophysics Geosystems 11. 
von Deimling, J.S., Rehder, G., Greinert, J., McGinnnis, D.F., Boetius, A., Linke, P., 2011. Quantification of seep-related methane gas emissions at Tommeliten, North Sea. Continental Shelf Research 31, 867-878.

Waseda, A., Iwano, H., 2008. Characterization of natural gases in Japan based on molecular and carbon isotope compositions. Geofluids 8, 286-292.

Weinstein, A., Navarrete, L., Ruppel, C., Weber, T.C., Leonte, M., Kellermann, M.Y., Arrington, E.C., Valentine, D.L., Scranton, M.I., Kessler, J.D., 2016. Determining the flux of methane into Hudson Canyon at the edge of methane clathrate hydrate stability. Geochemistry Geophysics Geosystems 17, 3882-3892.

Westbrook, G.K., Thatcher, K.E., Rohling, E.J., Piotrowski, A.M., Palike, H., Osborne, A.H., Nisbet, E.G., Minshull, T.A., Lanoiselle, M., James, R.H., Huhnerbach, V., Green, D., Fisher, R.E., Crocker, A.J., Chabert, A., Bolton, C., Beszczynska-Moller, A., Berndt, C., Aquilina, A., 2009. Escape of methane gas from the seabed along the West Spitsbergen continental margin. Geophysical Research Letters 36.

Whiticar, M.J., 1994. Correlation of natural gases with their sources. AAPG Memoir, Magoon, L. B.; Dow, W. G. (Eds), The petroleum System: from Sources to Trap vol.60, pp 261-283.

Whiticar, M.J., 1999. Carbon and hydrogen isotope systematics of bacterial formation and oxidation of methane. Chemical Geology 161, 291-314.

Whiticar, M.J., Faber, E., Schoell, M., 1986. Biogenic methane formation in marine and freshwater environments: $\mathrm{CO} 2$ reduction vs. acetate fermentation--Isotope evidence. Geochimica et Cosmochimica Acta 50, 693-709.

Zitter, T., Henry, P., Aloisi, G., Delaygue, G., Çagatay, M., Mercier de Lepinay, B., Al-Samir, M., Fornacciari, F., Tesmer, M., Pekdeger, A., 2008. Cold seeps along the main Marmara fault in the Sea of Marmara (Turkey). Deep-Sea Research Part I 55, 552-570.

Zitter, T.A.C., Grall, C., Henry, P., Ozeren, M.S., Cagatay, M.N., Sengor, A.M.C., Gasperini, L., de Lepinay, B.M., Geli, L., 2012. Distribution, morphology and triggers of submarine mass wasting in the Sea of Marmara. Marine Geology 329, 58-74. 
Table 1 : Molecular compositions of the sampled gas seeps

\begin{tabular}{|c|c|c|c|c|c|c|c|c|c|c|c|c|c|}
\hline \multicolumn{14}{|c|}{$\%-\mathrm{mol}$} \\
\hline Sample name & Site location & methane & e ethane & propane & $\begin{array}{c}\text { iso- } \\
\text { butane }\end{array}$ & $\begin{array}{c}\mathrm{n}- \\
\text { butane }\end{array}$ & $\begin{array}{c}\text { Neo- } \\
\text { pentane }\end{array}$ & $\begin{array}{c}\text { Iso- } \\
\text { pentane }\end{array}$ & $\begin{array}{c}n- \\
\text { pentane }\end{array}$ & n-hexane & $\begin{array}{l}\text { Carbon } \\
\text { dioxide }\end{array}$ & Nitrogen & Hydrogen sulfide \\
\hline $\begin{array}{l}\text { MRS-DV1- } \\
\text { PE02 }\end{array}$ & & 98,71 & 0,4713 & 0,0069 & 0,0013 & 0,0004 & 0,0029 & 0,0002 & & 0,0000 & 0,5498 & 0,2480 & 0,0000 \\
\hline $\begin{array}{l}\text { MRS-DV1- } \\
\text { PE03 }\end{array}$ & Central High & 98,65 & 0,7486 & 0,0026 & 0,0704 & 0,0001 & 0,0043 & 0,0266 & & 0,0000 & 0,1382 & 0,3609 & 0,0000 \\
\hline PG-1664 & & 98,86 & 0,48 & 0,24 & 0,0039 & 0,001 & 0,003 & 0,0007 & 0,0003 & 0,007 & 0,36 & 0,26 & - \\
\hline $\begin{array}{l}\text { MRS-DV2- } \\
\text { PE01 }\end{array}$ & & 87,61 & 1,0574 & 2,4845 & 0,8340 & 0,1312 & 0,0035 & 0,2342 & & 0,0004 & 7,6480 & 0,0000 & 0,0000 \\
\hline $\begin{array}{l}\text { MRS-DV2- } \\
\text { PE02 }\end{array}$ & $\begin{array}{l}\text { Western } \\
\text { High }\end{array}$ & 82,39 & 3,5348 & 3,9507 & 0,9163 & 0,3996 & 0,0031 & 0,2042 & & 0,0009 & 8,6000 & 0,0000 & 0,0000 \\
\hline PG-1662 & & 90,90 & 1,23 & 2,50 & 0,93 & 0,15 & 0,0034 & 0,31 & 0,010 & 0,0017 & 3,90 & - & - \\
\hline $\begin{array}{l}\text { MRS-DV3- } \\
\text { PE01 }\end{array}$ & & 94,76 & 1,7529 & 0,9124 & 0,3239 & 0,0467 & 0,0057 & 0,2228 & & 0,0072 & 1,5887 & 0,2113 & 0,1782 \\
\hline $\begin{array}{l}\text { MRS-DV3- } \\
\text { PE02 }\end{array}$ & & 87,5 & 1,3 & 0,77 & 0,26 & 0,26 & 0,003 & 0,22 & & 0,619 & 8,2 & 0,9 & 0,0000 \\
\hline $\begin{array}{l}\text { MRS-DV3- } \\
\text { PE03 }\end{array}$ & $\begin{array}{l}\text { Western } \\
\text { flanck }\end{array}$ & 2,01 & 0,1286 & 0,0458 & 0,0104 & 0,0140 & 0,0000 & 0,0063 & & 0,0014 & 97,6438 & 0,2126 & 0,0000 \\
\hline $\begin{array}{l}\text { MRS-DV3- } \\
\text { PE04 }\end{array}$ & $\begin{array}{l}\text { Tekirdağ } \\
\text { Basin }\end{array}$ & 99,29 & 0,0909 & 0,0191 & 0,0025 & 0,0003 & 0,0039 & 0,0003 & & 0,0000 & 0,1703 & 0,3977 & 0,0264 \\
\hline $\begin{array}{l}\text { MRS-DV3- } \\
\text { PE06 }\end{array}$ & & 94,48 & 1,7687 & 0,9194 & 0,3232 & 0,0492 & 0,0055 & 0,2230 & & 0,0049 & 1,9461 & 0,1830 & 0,0988 \\
\hline $\begin{array}{l}\text { MRS-DV3- } \\
\text { PE09 }\end{array}$ & & 99,53 & 0,0568 & 0,0058 & 0,0012 & 0,0001 & 0,0010 & 0,0001 & & 0,0000 & 0,1142 & 0,2237 & 0,0671 \\
\hline
\end{tabular}




\begin{tabular}{|c|c|c|c|c|c|c|c|c|c|c|c|c|c|}
\hline $\begin{array}{l}\text { MRS-DV4- } \\
\text { PE02 }\end{array}$ & Southeastern & 99,79 & 0,0147 & 0,0014 & 0,0000 & 0,0000 & 0,0000 & 0,0000 & & 0,0000 & 0,0950 & 0,1019 & 0,0000 \\
\hline $\begin{array}{l}\text { MRS-DV4- } \\
\text { PE07 }\end{array}$ & $\begin{array}{c}\text { flanck } \\
\text { Tekirdağ }\end{array}$ & 99,67 & 0,0044 & 0,0007 & 0,0000 & 0,0000 & 0,0000 & 0,0000 & & 0,0000 & 0,0873 & 0,2357 & 0,0000 \\
\hline $\begin{array}{l}\text { MRS-DV4- } \\
\text { PE08 }\end{array}$ & Basin & 99,53 & 0,0030 & 0,0010 & 0,0002 & 0,0001 & 0,0000 & 0,0001 & & 0,0000 & 0,0905 & 0,3590 & 0,0151 \\
\hline $\begin{array}{l}\text { MRS-DV5- } \\
\text { PE01 }\end{array}$ & & 99,68 & 0,0052 & 0,0013 & 0,0003 & 0,0002 & 0,0000 & 0,0001 & & 0,0000 & 0,1359 & 0,1728 & 0,0000 \\
\hline $\begin{array}{c}\text { MRS-DV5- } \\
\text { PE02 }\end{array}$ & & 99,74 & 0,0066 & 0,0020 & 0,0003 & 0,0002 & 0,0000 & 0,0001 & & 0,0000 & 0,1328 & 0,1150 & 0,0000 \\
\hline $\begin{array}{c}\text { MRS-DV5- } \\
\text { PE03 }\end{array}$ & $\begin{array}{c}\text { ÇInarcık } \\
\text { Basin }\end{array}$ & 99,74 & 0,0060 & 0,0016 & 0,0004 & 0,0001 & 0,0000 & 0,0001 & & 0,0000 & 0,0890 & 0,1642 & 0,0000 \\
\hline $\begin{array}{l}\text { MRS-DV5- } \\
\text { PE04 }\end{array}$ & & 99,61 & 0,0546 & 0,0121 & 0,0024 & 0,0002 & 0,0000 & 0,0001 & & 0,0000 & 0,1837 & 0,1120 & 0,0209 \\
\hline PG-1659 & & 99,63 & 0,0048 & 0,0012 & 0,0003 & 0,0003 & - & 0,0002 & - & 0,0007 & 0,10 & 0,26 & - \\
\hline
\end{tabular}


Table 2 : Stable carbon and hydrogen isotopic compositions of the sampled gas seeps

\begin{tabular}{|c|c|c|c|c|c|c|c|c|c|c|c|c|}
\hline \multicolumn{11}{|c|}{$\delta^{13} \mathrm{C} / \% 0$} & \multirow{2}{*}{$\frac{\delta \mathrm{D} / \% 0}{\text { methane }}$} & \multirow[b]{2}{*}{$C 1 /(C 2+C 3)$} \\
\hline Sample name & Site location & methane & ethane & propane & i-butane & n-butane & $\begin{array}{c}\text { Neo- } \\
\text { pentane }\end{array}$ & i-pentane & n-pentane & $\begin{array}{l}\text { Carbon } \\
\text { dioxide }\end{array}$ & & \\
\hline MRS-DV1-PE02 & & -43.5 & -23.4 & -6.8 & -14.8 & -8.5 & - & -16.8 & - & +25.5 & & 195 \\
\hline MRS-DV1-PE03 & Central High & -53.0 & -21.7 & -6.8 & -22.1 & - & - & -21.5 & - & +4.6 & -210 & 125 \\
\hline PG-1664 & & -44.4 & -22.8 & -9.8 & -19.4 & -8.9 & -24.7 & -16.6 & -21.1 & +25.4 & -223 & 137 \\
\hline MRS-DV2-PE01 & \multirow{3}{*}{$\begin{array}{l}\text { Western } \\
\text { High }\end{array}$} & -44.6 & -26.3 & -21.2 & -28.1 & -20.5 & - & -26.1 & -18.0 & - & -222 & 24 \\
\hline MRS-DV2-PE02 & & -44.0 & -28.3 & -24.9 & -28.3 & -22.3 & - & -26.2 & -18.0 & +28.4 & -229 & 11 \\
\hline PG-1662 & & -44.4 & -25.7 & -21.1 & -28 & -20.1 & - & -25.3 & -18.9 & +29.1 & & 24.4 \\
\hline MRS-DV3-PE01 & \multirow{6}{*}{$\begin{array}{l}\text { Western } \\
\text { flanck } \\
\text { Tekirdağ } \\
\text { Basin }\end{array}$} & -52.3 & -26.0 & -22.0 & -26.0 & -11.0 & - & -24.9 & -11.0 & +12.0 & -218 & 35 \\
\hline MRS-DV3-PE02 & & -57.3 & -26.9 & -24.4 & -26.7 & -24.5 & - & -25.8 & -23.2 & - & -173 & 42 \\
\hline MRS-DV3-PE03 & & -34.0 & -26.8 & -24.9 & -26.2 & -24.5 & - & -25.4 & -24.5 & -3.7 & -216 & 11 \\
\hline MRS-DV3-PE04 & & -54.8 & -17.7 & +4.5 & - & -12.2 & - & -24.9 & - & -14.2 & -213 & 872 \\
\hline MRS-DV3-PE06 & & -52.2 & -26.0 & -22.1 & -26.0 & -11.4 & 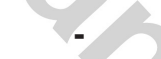 & -24.9 & -11.0 & +16.9 & -215 & 34 \\
\hline MRS-DV3-PE09 & & -58.4 & -24.0 & -6.2 & -15.6 & -14.4 & - & -14.8 & - & -20.6 & & 1511 \\
\hline MRS-DV4-PE02 & Southeastern & -63.8 & -33.4 & -26.1 & - & - & - & & - & -0.8 & -237 & 5424 \\
\hline MRS-DV4-PE07 & flanck & -66.1 & -36.1 & -30.3 & - & - & - & & - & -5.6 & -243 & 17190 \\
\hline MRS-DV4-PE08 & $\begin{array}{l}\text { Tekirdağ } \\
\text { Basin }\end{array}$ & -66.0 & -37.3 & -31.9 & -29.1 & - & - & & 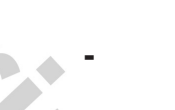 & -19.0 & - & 22636 \\
\hline MRS-DV5-PE01 & \multirow{5}{*}{$\begin{array}{c}\text { Çınarcık } \\
\text { Basin }\end{array}$} & -63.5 & -38.7 & -34.4 & -32.7 & -30.0 & - & -30.3 & 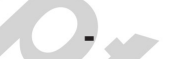 & -3.4 & -251 & 13847 \\
\hline MRS-DV5-PE02 & & -63.1 & -38.4 & -34.3 & -33.0 & -29.3 & - & -30.3 & & -5.9 & -248 & 9980 \\
\hline MRS-DV5-PE03 & & -63.8 & -38.7 & -34.0 & -32.9 & -28.3 & - & -30.0 & - & -6.0 & -228 & 12321 \\
\hline MRS-DV5-PE04 & & -62.1 & -32.9 & -27.5 & -25.1 & -23.2 & - & -25.8 & - & -15.0 & & 1424 \\
\hline PG-1659 & & -64.1 & -37.6 & -30.9 & -30.2 & -27.8 & - & -28.3 & - & -6.4 & & 16600 \\
\hline
\end{tabular}


Table 3 : He isotopic ratios and ${ }^{4} \mathrm{He} /{ }^{20} \mathrm{Ne}$ ratios for the collected bubble gases. Errors $(2 \sigma)$ are typically $4 \%$ and $10 \%$, respectively. The helium isotopic ratios are expressed as multiples of the atmospheric ${ }^{3} \mathrm{He} /{ }^{4} \mathrm{He}$ ratio $\left(\mathrm{R}_{\mathrm{a}}=1.38 \times 10^{-6}\right.$; Ozima and Podosek, 2002). The ${ }^{4} \mathrm{He} /{ }^{20} \mathrm{Ne}$ ratios trace the extent of contamination by atmospheric gases $\left({ }^{4} \mathrm{He} /{ }^{20} \mathrm{Ne}\right.$ is $0.32 \mathrm{in}$ air, and $>1,000$ in the mantle)

\begin{tabular}{l|c|c|c}
\hline Sample name & Site location & ${ }^{3} \mathrm{He} /{ }^{4} \mathrm{He}(\mathrm{Ra})$ & ${ }^{4} \mathrm{He} /{ }^{20} \mathrm{Ne}$ \\
\hline MRS-DV02-PE02 & Western High & 0,05 & 6,95 \\
MRS-DV02-PE01 & & 0,87 & 0,75 \\
MRS-DV03-PE06 & Western flanck & 5,25 & 439 \\
MRS-DV03-PE01 & Tekirdağ Basin & 4,81 & 307 \\
MRS-DV04-PE08 & Southeastern flanck & & 2,98 \\
MRS-DV04-PE02 & Tekirdağ Basin & 0,35 & 1,21 \\
MRS-DV05-PE04 & Çınarcık Basin & 0,73 & 148 \\
MRS-DV05-PE02 & & 0,22 & 4,74 \\
\hline & & 0,25 & \\
\hline
\end{tabular}


Table 4 : Estimation of the level of mixing between the identified methane sources.

\begin{tabular}{|c|c|c|c|c|c|}
\hline Sample name & Site location & $\begin{array}{c}\text { Thermogenic } \\
\text { gases }\end{array}$ & $\begin{array}{l}\text { Microbial gases from secondary } \\
\text { methanogenesis }\end{array}$ & $\begin{array}{c}\text { Microbial gases from } \\
\text { primary } \\
\text { methanogenesis }\end{array}$ & $\mathrm{CO}_{2}$-rich source \\
\hline MRS-DV1-PE02 & & primarily & present & undetermined & 0 \\
\hline MRS-DV1-PE03 & Central High & primarily & present & undetermined & 0 \\
\hline MRS-DV2-PE01 & Western & 66 & 34 & & 0 \\
\hline MRS-DV2-PE02 & High & 66 & 34 & & 0 \\
\hline MRS-DV3-PE01 & & 39 & 61 & 0 & 0 \\
\hline MRS-DV3-PE02 & Western & 25 & 0 & 68 & 7 \\
\hline MRS-DV3-PE03 & flanck & 2,4 & 0 & 0 & 97.6 \\
\hline MRS-DV3-PE04 & Tekirdağ & primarily & present & undetermined & 0 \\
\hline MRS-DV3-PE06 & Basin & 39 & 61 & 0 & 0 \\
\hline MRS-DV3-PE09 & & primarily & present & undetermined & 0 \\
\hline MRS-DV4-PE02 & Southeastern & $\sim 0$ & 0 & $\sim 100$ & 0 \\
\hline MRS-DV4-PE07 & flanck & $\sim 0$ & 0 & $\sim 100$ & 0 \\
\hline MRS-DV4-PE08 & $\begin{array}{c}\text { Tekirdağ } \\
\text { Basin }\end{array}$ & $\sim 0$ & 0 & $\sim 100$ & 0 \\
\hline MRS-DV5-PE01 & & 2 & 0 & 99 & 0 \\
\hline MRS-DV5-PE02 & Çınarcık & 2 & 0 & 98 & 0 \\
\hline MRS-DV5-PE03 & Basin & $\sim 0$ & 0 & $\sim 100$ & 0 \\
\hline MRS-DV5-PE04 & & 6 & 0 & 94 & 0 \\
\hline
\end{tabular}

The thermogenic sources are different for the Western High and the Central High, and two other thermogenic sources are connected to the seeps in the Tekirdag Basin represented by the samples MRS-DV3-PE01 and MRS-DV3-PE06, MRS-DV3-PE04 and MRS-DV3-PE09, respectively. 


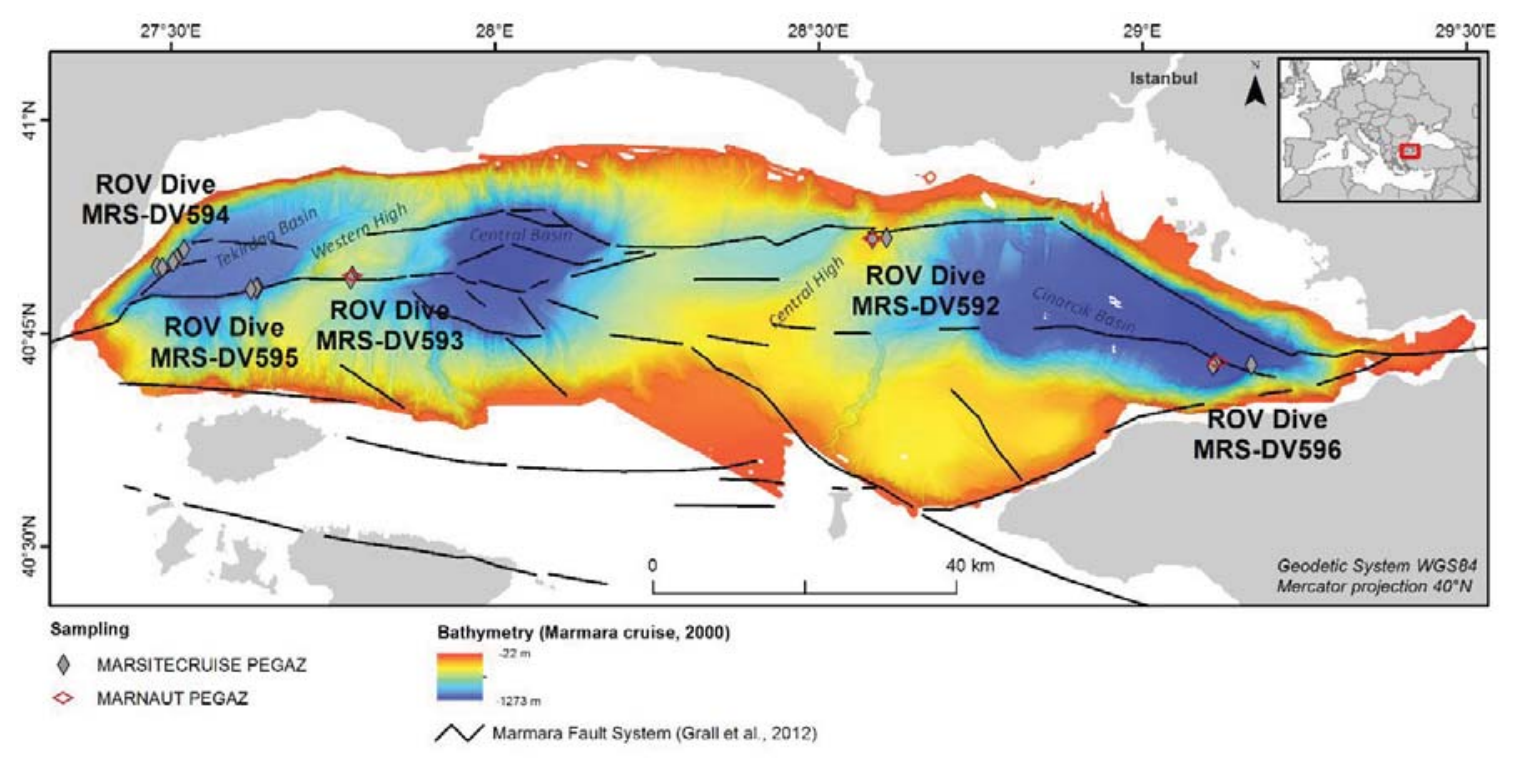

Figure 1: Map of the Sea of Marmara showing the locations of the five ROV dives 

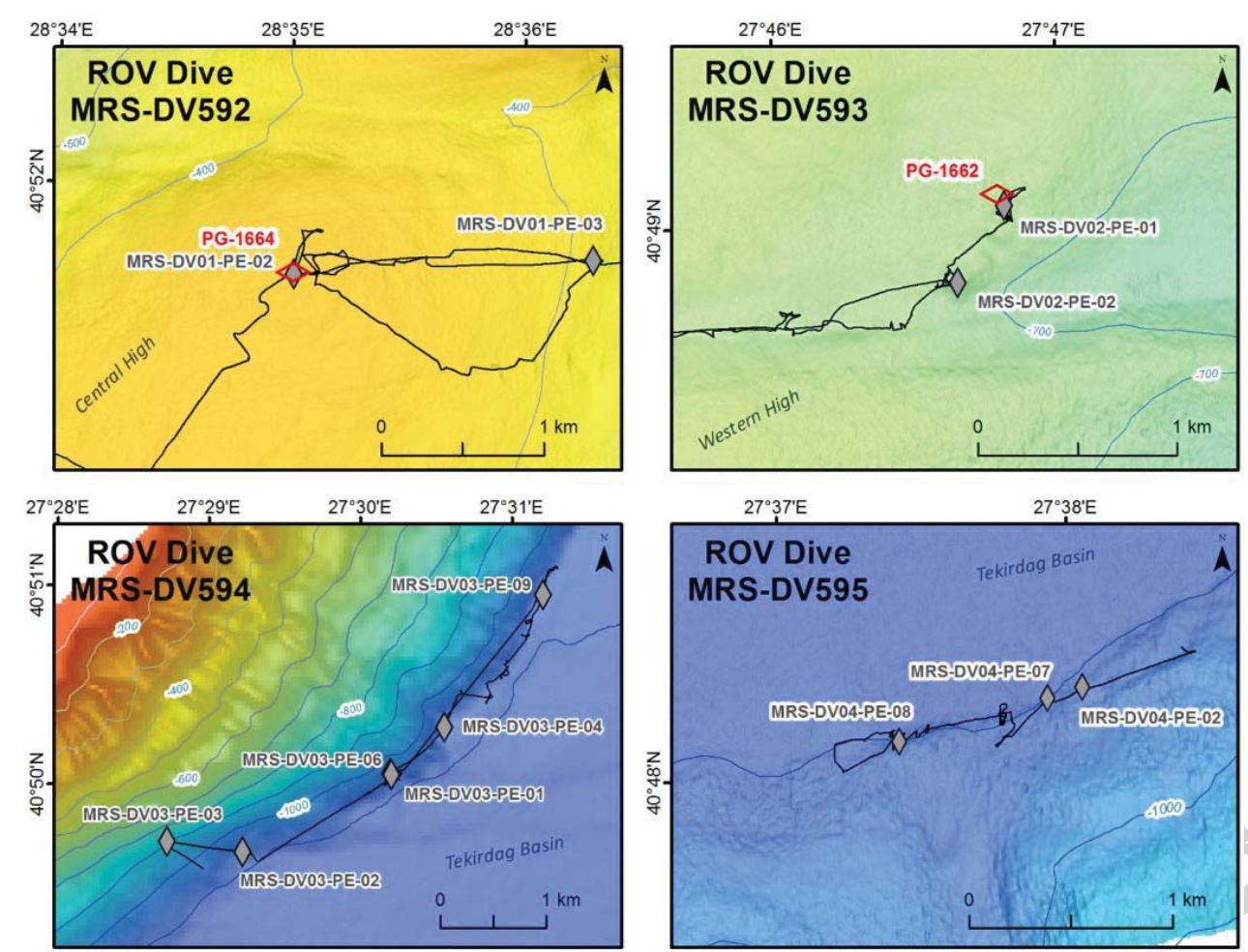

$27^{\circ} 37^{\circ} \mathrm{E}$
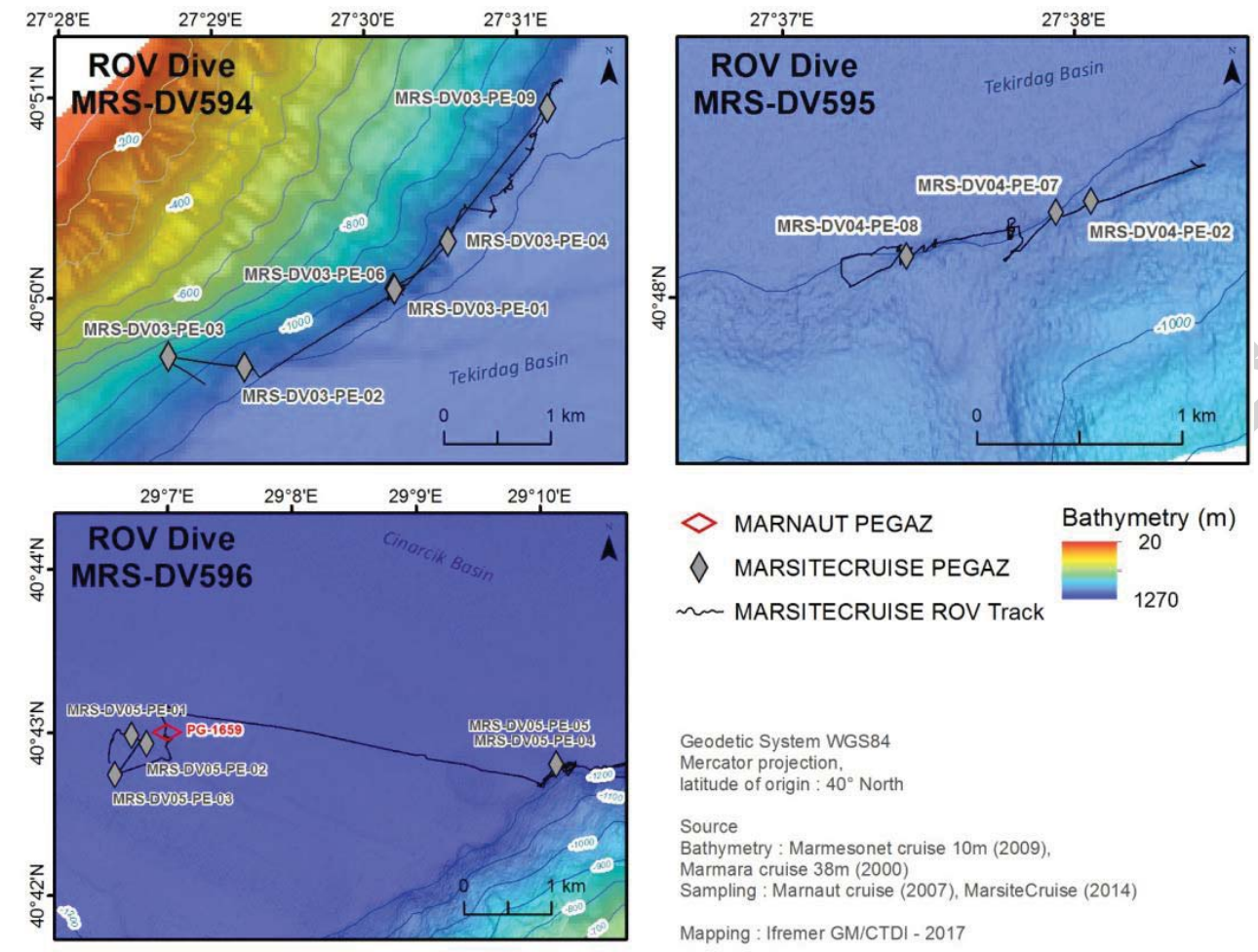

Geodetic System WGS84

Mercator projection,
latitude of origin : $40^{\circ}$ North

Source

Bathymetry : Marmesonet cruise 10m (2009),

Sampling : Marnaut cruise (2007), MarsiteCruise (2014)

Mapping : Ifremer GM/CTDI - 2017 
Figure 2: Magnified view of each dive showing the position of the sampled gas seeps.

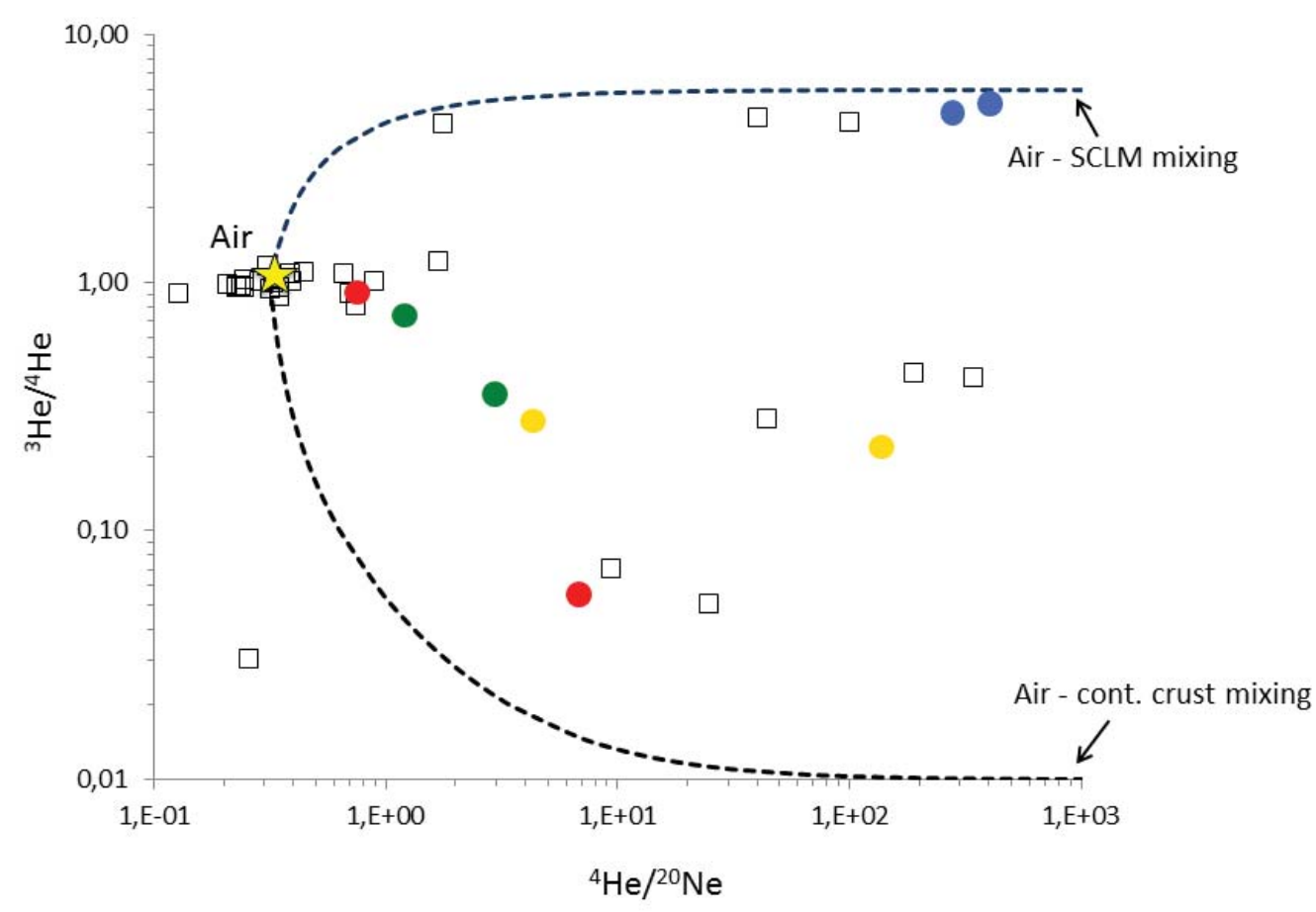

Figure 3: He isotope and ${ }^{4} \mathrm{He} /{ }^{20} \mathrm{Ne}$ ratio for the gas bubbles. SCLM stands for sub-continental lithospheric mantle (which referes to mantle helium ) and cont. crust for the continental crust. Color code for the symbols is as follows: Yellow star corresponds to the air value, empty square to the measurements from 
Burnard et al. (2012); dot to our measurements with black dot to dive MRS-DV593 (not measured for noble gas), red to dive MRS-DV593, blue to dive MRSDV594, green to dive MRS-DV595, yellow to dive MRS-DV596.

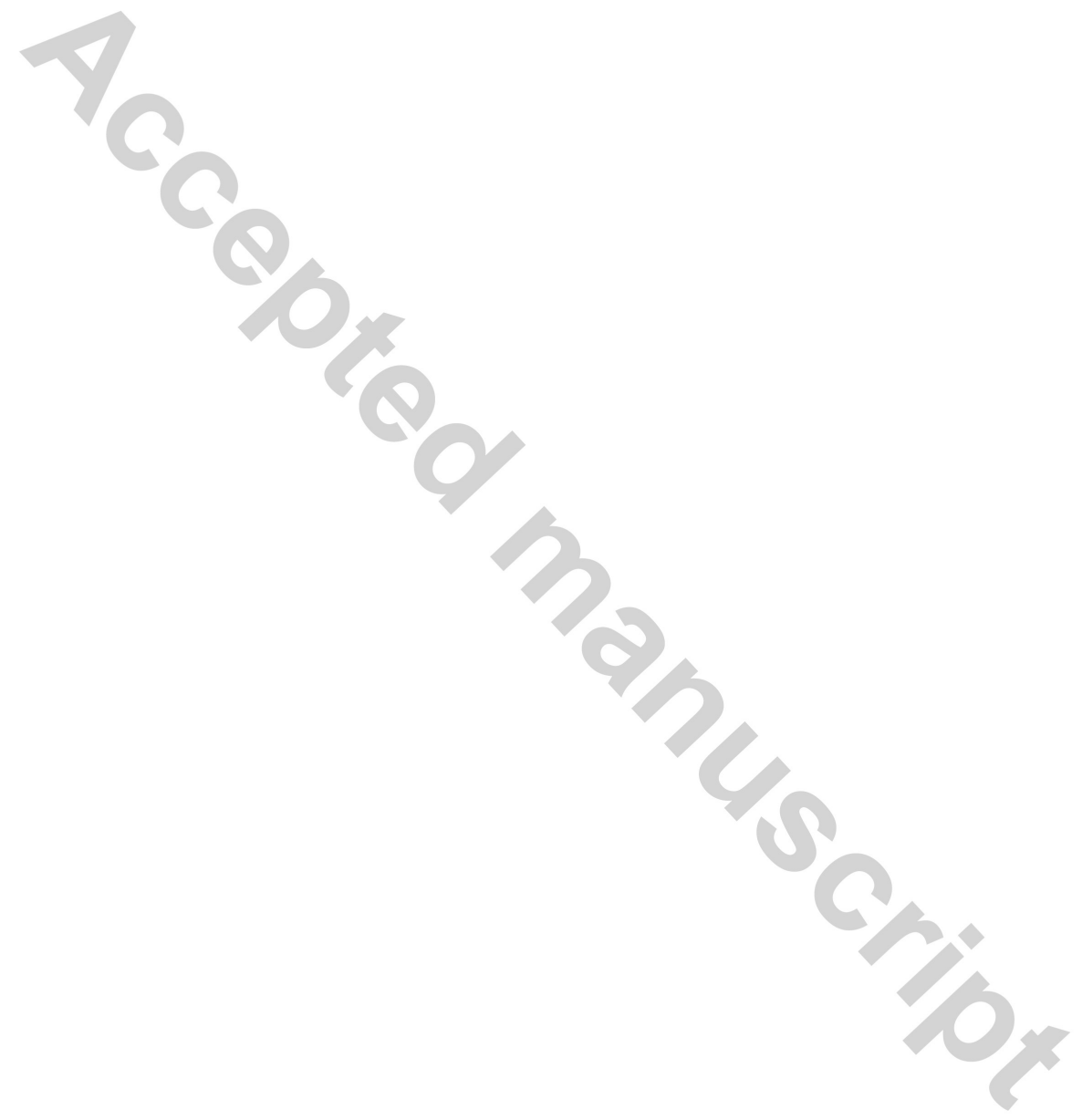




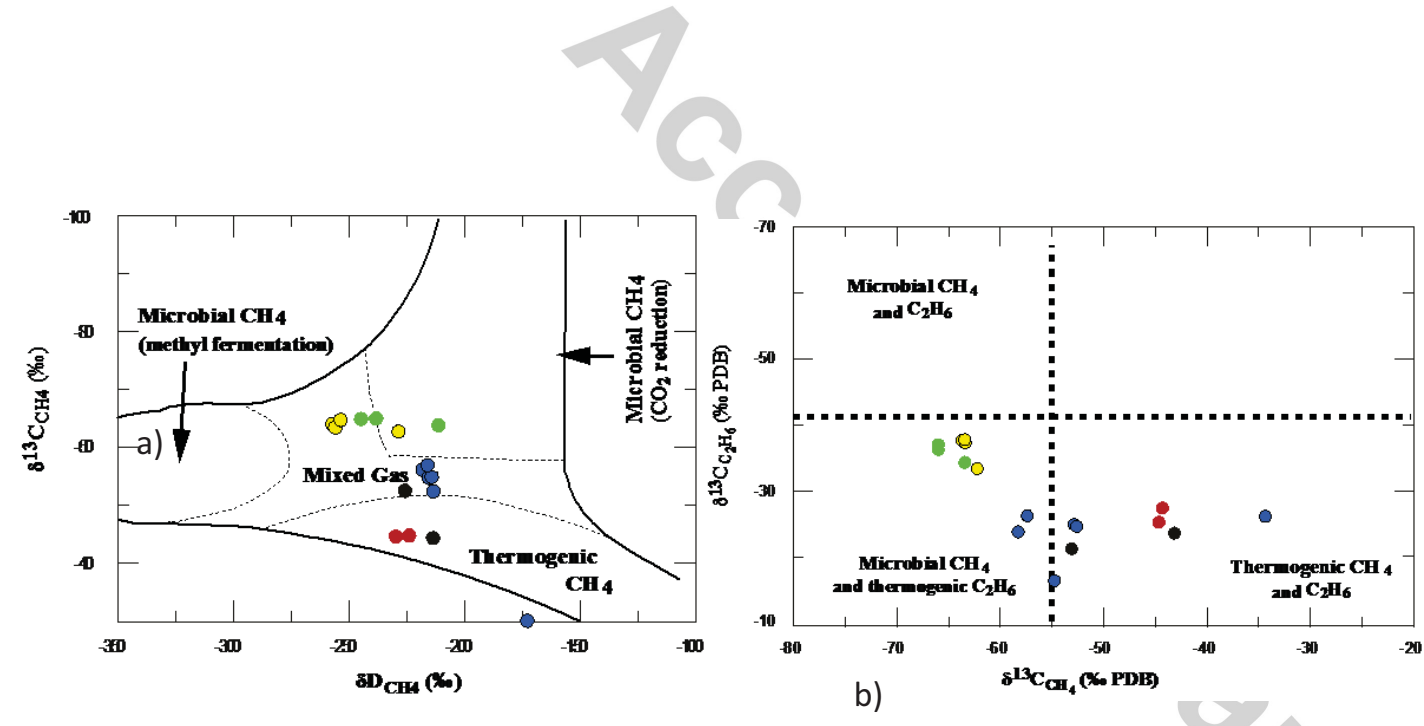




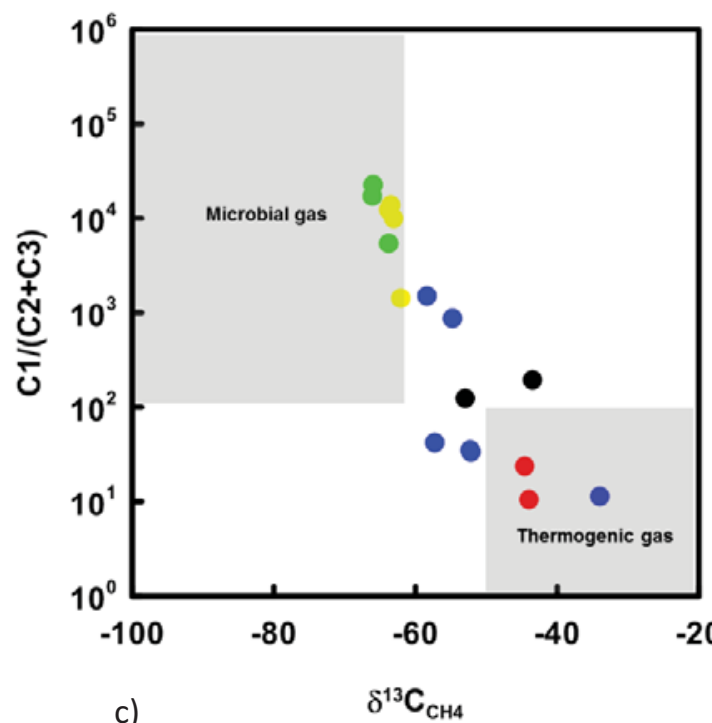

c)

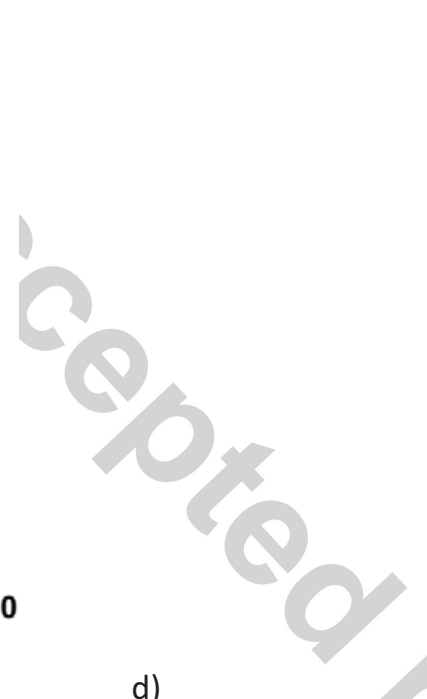

d)

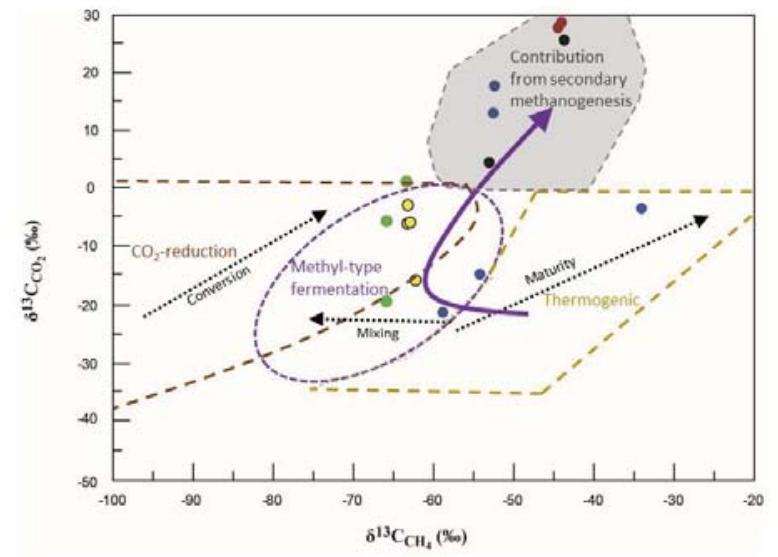

Figure 4: a) Diagram of methane hydrogen and carbon stable isotope compositions for the studied venting gases (modified after Schoell, 1983 and Whiticar, 1999); b) Diagram of carbon stable isotope composition of methane vs. ethane for the study sites (modified after Milkov, 2005); c) Diagram of methane carbon stable isotope composition vs. ethane and propane molecular compositions for the studied venting gases (modified after Bernard, 1978); ); d) Diagram of carbon stable isotope composition of methane vs. carbon dioxide for the study sites (modified after Milkov, 2011). See Figure 3 for color code. 

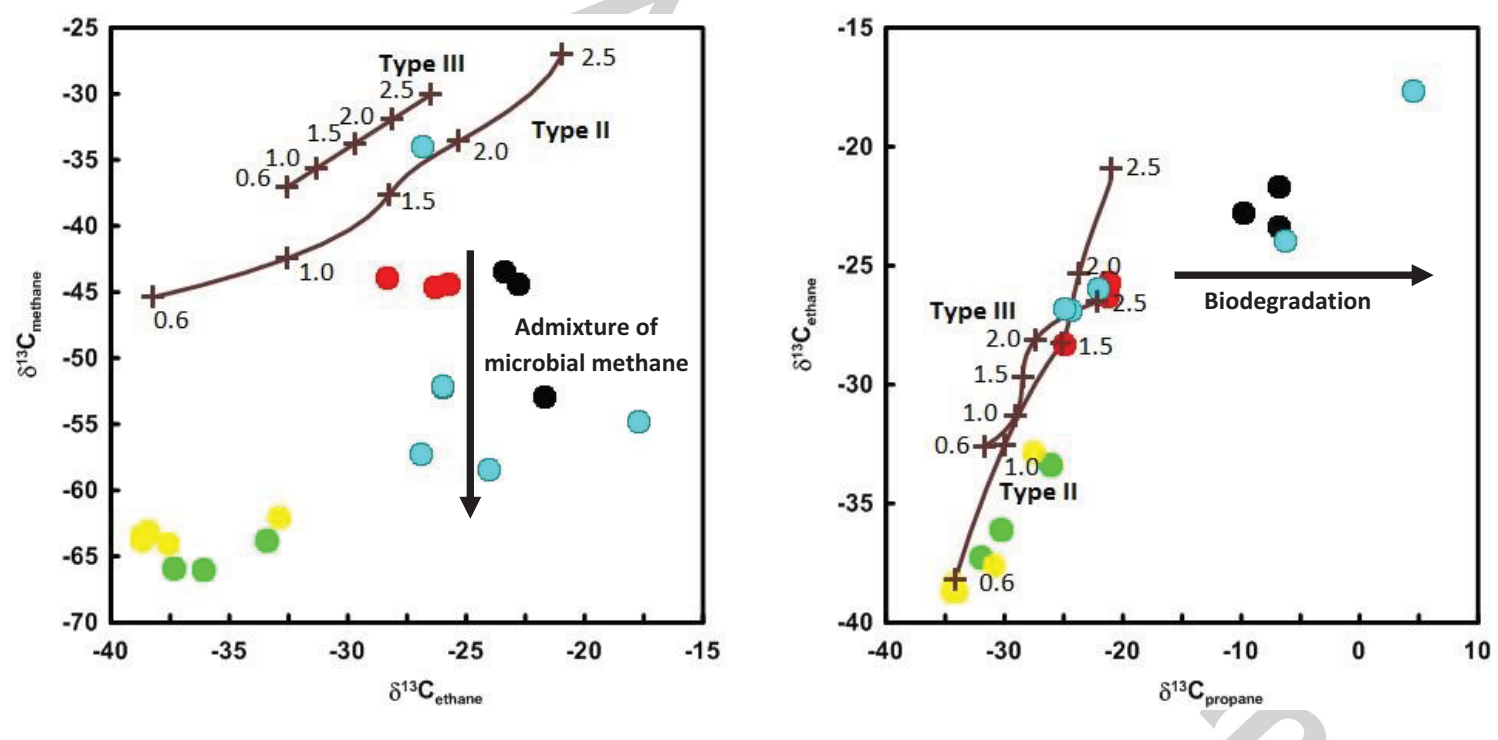

Figure 5: Maturity diagrams based on the $\delta^{13} \mathrm{C}$ of methane, ethane and propane for the gas samples. Isotopic composition of the marine (type II) and terrestrial (type III) kerogens was set to $-29 \%$ and $-30 \%$, respectively (after Hoşgörmez et al. (2005) and Gürgey et al. (2005)). See Figure 3 for color code. 

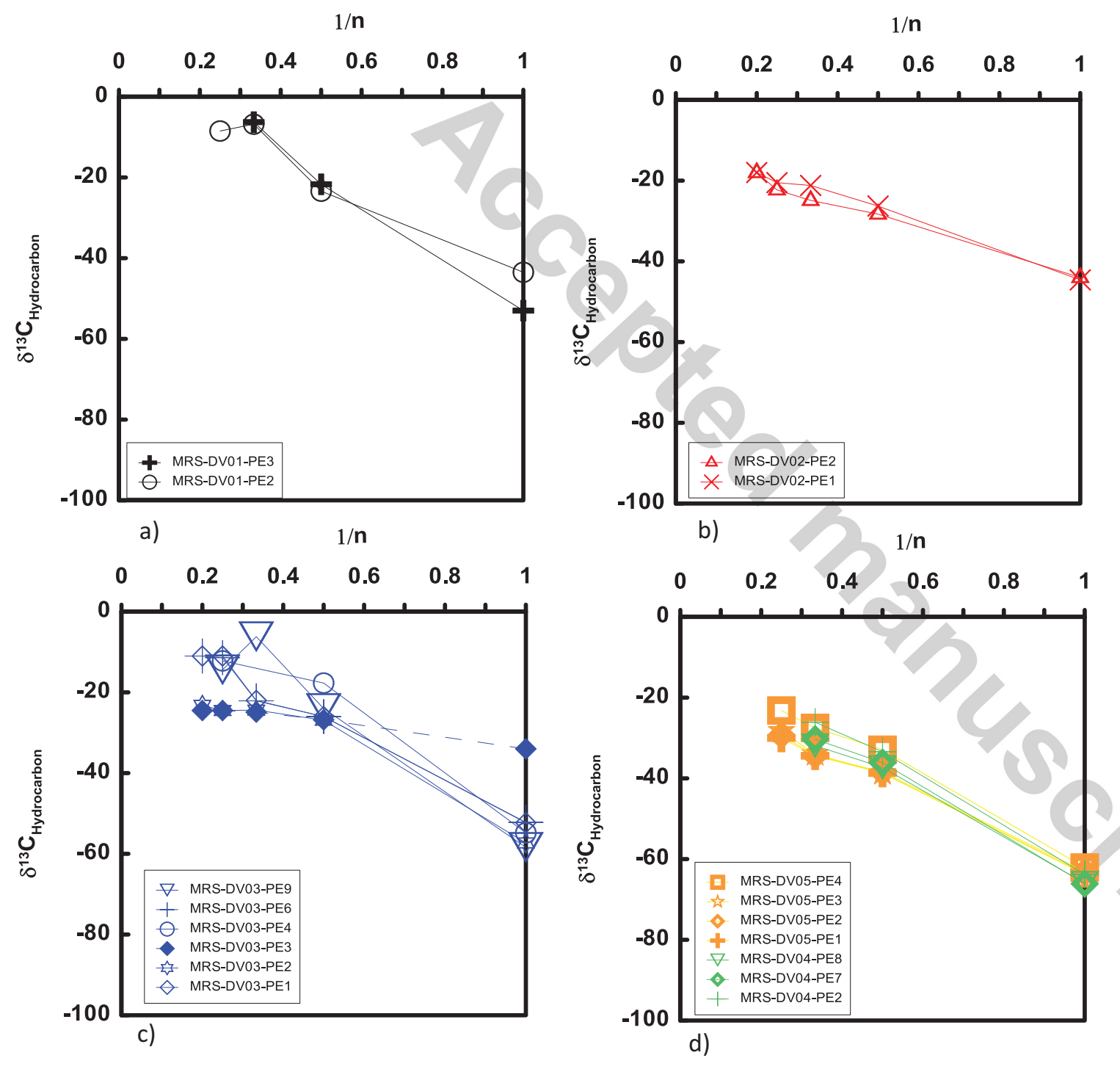
Figure 6: Chung diagram (Chung et al., 1988) applied to our seeps gases: a) Central High, b) Western High, c) The western flank of Tekirdag Basin, d) The southeastern flank of Tekirdag Basin (green) and Cinarcik Basin (yellow).
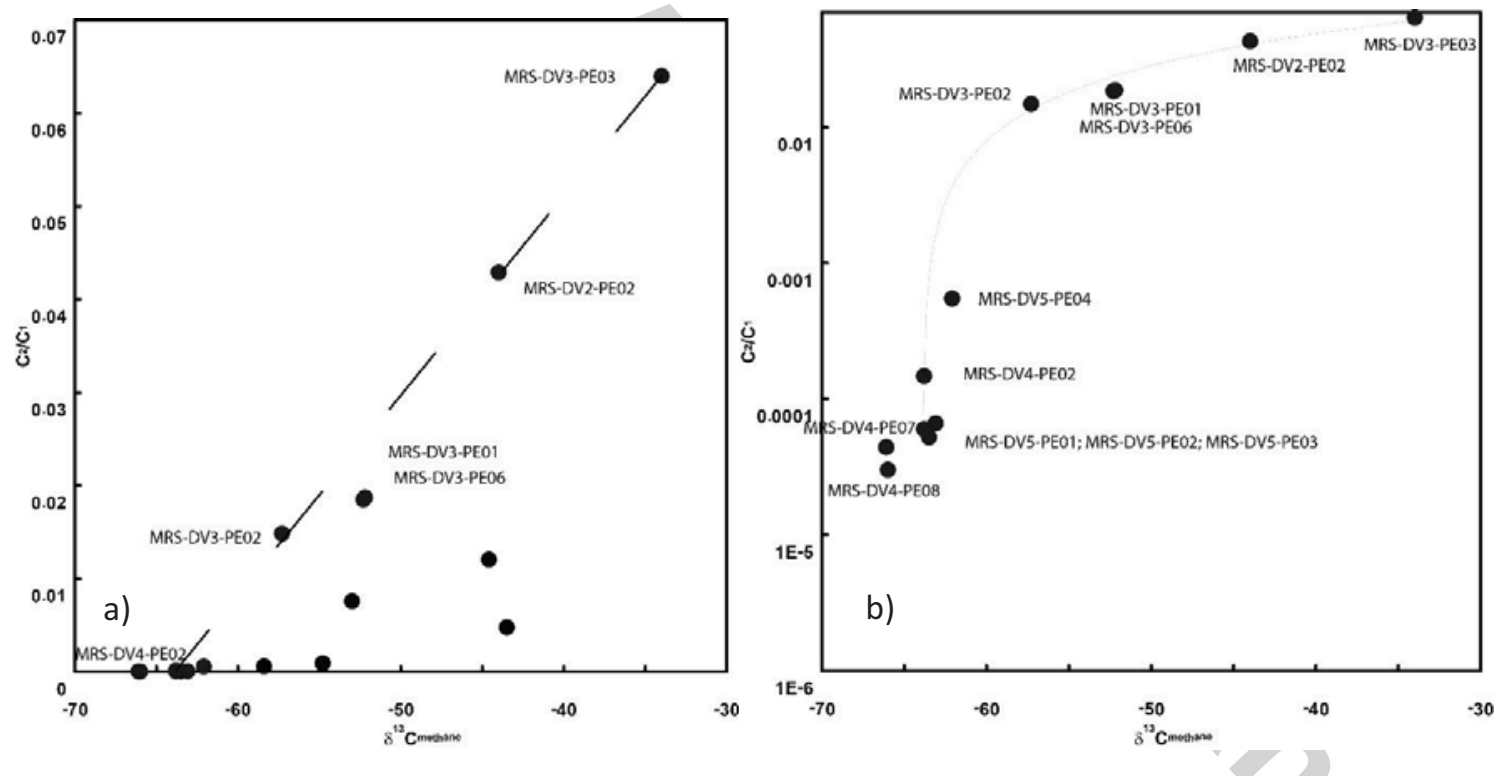

Figure 7: Diagram of the ethane-to-methane ratio as a function of the stable carbon isotope of methane (modified from Prinzhofer and Pernaton, 1997). a) linear scale and b) logarithmic scale. 